\title{
3 \\ Explorer memory and Aboriginal celebrity
}

\section{Catherine Bishop and Richard White}

In the nineteenth century, those men that the British world dubbed explorers - always men - were celebrities. The designated leaders of expeditions were distinguished from other members of their parties: they wrote the journals, won the accolades, obtained the honours and had their portraits done, while those who accompanied them generally faded into obscurity. Expeditions were recorded in popular culture by the names of their leaders. We still remember Mitchell, Leichhardt and Sturt, but seldom those who accompanied them, whether European or Indigenous. Aboriginal communities remember those expeditions and the Indigenous people who accompanied them differently, ${ }^{1}$ but this chapter is concerned with historical memory and popular celebrity in a white Australian context. The myth of the lone explorer has been debunked in late twentieth-century scholarship, with a range of historians describing the infrastructure and personnel, including Indigenous participants, that underpinned most expeditions. ${ }^{2}$ Other studies have begun to focus on the women who accompanied various expeditions, and recently the details of the convict who guided Blaxland, Wentworth and Lawson over the Blue Mountains in 1813 have been retrieved. ${ }^{3}$ As other chapters in this volume show, the sources for such

\footnotetext{
See Fred Cahir's chapter in Clarke and Cahir 2013.

See Reynolds 1990; Driver 2013; Kennedy 2013, esp. chapter 8.

Cadzow 2002; Yeats 2013.
} 
studies are often sparse. Our particular concern in this chapter, by contrast, is those Indigenous guides who - despite the prevalence of the myth of the lone explorer - were acknowledged and even celebrated for their contribution to Australian exploration, and who are also reasonably well documented within the archives of exploration.

Throughout the nineteenth and into the twentieth century, Indigenous people accompanied European explorers in Australia. Usually but not always men, they were guides, interpreters, negotiators, collectors, hunters, providores, cooks, servants and stockmen, their multiplicity of roles similar to that of other members of the expedition, whether European or Indigenous. For convenience we use the terms 'companion' and 'guide' throughout this chapter, although, as at least one companion suggested, 'explorer', which we use for leaders of expeditions, might well be a more appropriate appellation for many of these Indigenous men. Don Baker usefully categorised Thomas Mitchell's Aboriginal companions into four groups. There were the hired help, who were independent contractors familiar with European society, essentially simply providing labour. There were those he termed 'passers on', who often had no English. These were locals met with along the way; they simply wanted to ensure the expedition passed on with as little disruption to their territory and lives as possible. A third group, camp followers, often women or young boys, attached themselves to the expedition without payment and with varying degrees of perceived usefulness. ${ }^{4}$ Most highly valued were the professionals, who were seen as particularly skilled and were taken on for the entirety of the expedition. Recent scholarship has argued that, given the use made of their knowledge, the contribution of these Indigenous companions deserves more recognition: their particular role in ensuring the success and often the very survival of an expedition has been generally underestimated. ${ }^{5}$

Underestimated they may have been, but they were not entirely ignored. Given the logic of imperialism and the racial politics of the exploration era, the surprise is that, while white expedition leaders were the focus of adulation, a surprising number of Indigenous participants became quite well known and were, at different times, minor celebrities. ${ }^{6}$ Those that Baker called 'professionals' were most likely to be individually recognised and memorialised in some form. It is remarkable how many there were and how sections of European society were willing to acknowledge them, both at the time and since. Where this recognition

\footnotetext{
$4 \quad$ Baker 1998.

Blyton 2012; Reynolds 1990; Host and Milroy 2001; Cahir 2010: 22.

See Kennedy 2013; and Driver 2013, who particularly notes that different types of indigenous assistance were accorded different levels of acknowledgement.
} 
has been noticed in the scholarship, it has often been characterised as simply patronising, grudging and/or unavoidable. This chapter seeks to probe further the nature of that recognition.

The celebration of explorers in the nineteenth and into the twentieth century was contingent upon a particular intersection of class, gender and race. Explorers were respectable, white men and exploration was often a means of social advancement for them. Leading an expedition gave men a status that marked them apart. Thus expedition parties were constructed to varying degrees upon master-servant lines - and this extended to their fellow Europeans. Edward Eyre, for example, referred to his European companion John Baxter as a 'faithful follower', using similar language to that which he used to describe his Aboriginal companion Wylie. This was also almost by definition a masculine world, and female participants were barely acknowledged at the time and even less remembered by posterity. Turendurey, guide and negotiator for Thomas Mitchell, was one of the few, and she was not much celebrated. ${ }^{7}$ Nevertheless, while in the popular imagination the explorer was a white male, that same popular imagination singled out particular Indigenous individuals for attention throughout the nineteenth century. Men such as Jackey Jackey, Wylie, Yuranigh, Mokare and Tommy Windich acquired some fame in their lifetime and have been celebrated in various ways since. Often, as we will see, these were men whose relationship with the expedition leader was long-standing.

In the lifecycle of celebrity, there are four periods to consider. First there is the recognition received on the completion of an expedition, in the celebrations that followed and on publication of the journal. A second moment of recognition occurs upon the guide's death, when obituaries and memorials might appear. In both of these forms of acknowledgement, the expedition's leader was usually instrumental. The third and fourth phases in the cycle reflect a broader politics of social memory. The third is the period of Stanner's 'great Australian silence', when Aboriginal Australians were generally - though not altogether - written out of history. ${ }^{8}$ Stanner dates this from around the 1930s, although other historians find its origins in the closing decades of the nineteenth century. ${ }^{9}$ It is in this period that guides were most likely to be forgotten, and yet during a number of local expedition centenaries they were acknowledged in various ways. Finally, there is the period since the 1960s, when white Australia began to discover a black history.

\footnotetext{
7 Even the few white female explorers went unheralded: the diary of Emily Caroline Creaghe, who accompanied her husband and Ernest Favenc in the late nineteenth century, remained practically unnoticed in the Mitchell Library until the end of the twentieth century.

8 Stanner 1969.

9 Henry Reynolds dates the silence from the late nineteenth century, as white explorers became the heroes of Australian history, the 'discoverers' of Australia. Reynolds 2000: 18-20.
} 


\section{At the end of an expedition}

At the end of a successful expedition, there was generally a round of dinners and public occasions, when speeches were made, leaders were feted and exploring parties made much of. Explorers wrote up and published their journals, not only to record their achievements and to ensure and manage their public reputation, but also to make money. In the immediate aftermath of an expedition, the questions of who was recognised and for what were crucial because it could set the pattern for posterity. The focus was inevitably on the formal leader, but in their distribution of honours and credit, expedition leaders could not only acknowledge Indigenous participants but single them out for attention.

\section{Naming places}

One of the presumptions of European explorers was that they felt at liberty to name the natural features of the country through which they travelled. Some attempted to find out the local Indigenous names, regarding this as a more 'scientific' approach, but most took the opportunity to use the names of patrons, friends - or themselves. ${ }^{10}$ As Nigel Parbury says, credit for discovery was always attributed to the white men. ${ }^{11}$ Nevertheless the names given to places included those of both Indigenous and European expedition members, suggesting that the expedition leaders recognised something of a collaborative effort. In 1807 George Caley named Moowattin River after his Indigenous companion, Daniel Moowattin, who 'discovered' the Appin Falls. It appeared as the Moowattin River in the atlas accompanying Matthew Flinders' Voyage to Terra Australis in 1814, but was later renamed the Cataract River. ${ }^{12}$ In 1846 Thomas Mitchell named Yuranigh's Ponds in honour of one his guides, although perhaps in this case it was somewhat tongue in cheek, as Yuranigh had objected to sitting close to that stretch of water because of the danger of attack by 'wild natives'.$^{13}$ In $1874 \mathrm{John}$ Forrest named Windich and Pierre Springs, along the present day Canning Stock Route, in recognition of two of his Aboriginal companions. Windich Springs was an especially important find, 'a fine permanent spring', which Forrest characterised as 'the best springs I have ever seen'. According to one report, Tommy Pierre was the first to find 'his' spring, although this is not confirmed in Forrest's journal. ${ }^{14}$ The Jardine brothers overlanding in Queensland named a welcome watercourse Eulah Creek after 'the most trusty' of their 'black boys', 'old Eulah', who found it for them in $1865 .{ }^{15}$ Even Christie Palmerston, who is

\footnotetext{
$0 \quad$ Carter 1987.

1 Parbury 1986.

2 Smith 2005.

13 Mitchell 1848: 327 (25 September 1846).

14 South Australian Register, 7 November 1874: 2S; Forrest 1875, chapter 5: 28 May 1874.

15 Sharp 1992: 69; Jardine 1867, chapter 1.
} 
remembered in some circles as "prone to giving local Aborigines "a taste of the rifle"', named Pompo Falls in the Great Dividing Range after his 'blackboy' ${ }^{16}$ Given the central importance of water in Australian exploration, these namings were meaningful.

\section{Journals}

Explorers' journals are the primary surviving evidence for the roles of Indigenous guides. The mere fact that they are littered with the names of the Aboriginal men, who were finding water, hunting food, scouting new territory and negotiating with new people, shows that their role was not ignored by the journal writers. The writers could make negative comments - and when they were displeased tended to depict their Aboriginal companions as errant children, in keeping with contemporary tropes - but they also explicitly appreciated the skills they brought to the expedition. Dane Kennedy has suggested that this recognition was reluctant because admitting the contribution of Indigenous guides to the navigation and survival of the expedition potentially undermined the achievement of the European explorers themselves, particularly in a milieu in which the explorer was popularly conceived as a lone hero. ${ }^{17}$ However, the fact that these positive and even respectful remarks survived in the published version of the journals suggests that several expedition leaders willingly and publicly articulated not only their appreciation for but their reliance on the skills of the Aboriginal members of their party.

A number of guides received specific tributes in the published journals. Mitchell acknowledged John Piper as 'the most accomplished man in the camp' because of his bush skills and ability to communicate with and elicit information from other Aboriginal people encountered by the expedition. ${ }^{18} \mathrm{He}$ described Yuranigh as his 'guide, companion, councillor and friend'.$^{19}$ In 1841 Eyre was less confident about the loyalty and effectiveness of Wylie after the two other Indigenous guides on the expedition killed the only other white man, overseer John Baxter. Eyre wrote 'I was now deprived of my only aid ... left alone with a single native whose fidelity I could place no dependence on'. But in the end Eyre acknowledged Wylie's 'fidelity and good conduct'.$^{20}$ It was in Eyre's published journal that the image of himself and Wylie as 'the two sole wanderers' ${ }^{21}$ became the public face of the expedition. Long after Eyre left Australia he apparently maintained contact with Wylie. ${ }^{22}$

16 The Queenslander, 22 January 1881: 109; Pannell 2008: 61.

17 Kennedy 2013: 163.

18 Baker 1998: 44-45.

19 Mitchell 1848: 414, quoted in Baker 1998: 46.

20 The Sydney Herald, 30 August 1841: 2S; Eyre 1845: 7 July 1841.

21 Eyre 1845: 7 July 1841.

22 Dutton 1977. 


\section{Speeches, parades and dinners}

At the celebratory dinners that followed successful expeditions undertaken in the second half of the nineteenth century, speakers often acknowledged the contribution of Aboriginal guides. Sometimes Aboriginal guides were present at these quintessentially European occasions. In 1874, at a 'complimentary banquet' following Major Peter Warburton's explorations in the north of Western Australia, the two guests of honour were Warburton and his Aboriginal guide 'Charley'. Warburton spoke highly of his companions, including two Afghan cameleers, but reserved 'especial praise' for Charley, to whom, Warburton said, 'the lives of the whole party were due'. ${ }^{23}$ Charley's presence might be seen as merely providing an entertaining backdrop, but it also suggests a genuine acknowledgement of a sense of gratitude. In the same year, dinners for the Forrest brothers following their expeditions included Tommy Windich and Tommy Pierre, although the press reported that Windich seemed uncomfortable. ${ }^{24}$ At one public banquet, the colonial secretary praised Forrest's 'friend Windich' as 'the man who had brought Mr. Forrest to Adelaide, and not Mr. Forrest him' ${ }^{25}$ Pierre, on the other hand, seemed quite at ease and spoke himself at the celebrations in Fremantle. His words were recorded by the papers, albeit in somewhat patronising tones. Though the inclusion of Windich and Pierre at the dinner appeared equitable, distinctions were made in other public celebrations. In the street parade in Perth 'the aborigines, [were] riding on horses, gaily caparisoned, immediately behind the carriage containing Mr Forrest and the European members of his party'. ${ }^{26}$ The visual impact of this image is significant, underpinning their separateness and subordination, although perhaps also rendering them more visible and emphasising their role as bushmen. In contrast, in the Adelaide parade, the entire party was on horseback, and it is possible that the expedition leaders preferred to be seen that way, as men of action. The dinners and parades show a wider public were prepared to give at least some recognition to the role played by Indigenous guides.

\section{Rewards}

The material rewards bestowed on these guides were meagre and it is here perhaps that the lack of appropriate recognition is most stark. Given their roles, in which they were often responsible for the survival of their companions, they certainly benefitted less than other members of expeditions. In the hierarchies of the day there was no possibility that a reward to an Aboriginal worker might be commensurate with the value of the service provided.

23 South Australian Advertiser, 23 April 1874: 5.

24 The Inquirer \& Commercial News, 16 December 1874: 3.

25 Cited in Kennedy 2013:191.

26 Western Australian Times, 15 December 1874: 3. 
At the end of Leichhardt's 1845 expedition, the colonial secretary distributed $£ 1,000$ among its members: Leichhardt received £600; his adult European companions £125; a 16-year-old boy £70; a convict (who also received a government pension) £30; and Harry Brown and Charley Fisher, the Aboriginal guides, £25 each, the last deposited in a savings bank and drawn out only with the bank's approval. ${ }^{27}$ The distribution was determined not by Leichhardt himself but by the governor, who followed military conventions ${ }^{28}$ perhaps underscoring the way in which expeditions were conceived as hierarchical pseudo-military enterprises by authorities, or perhaps merely reflecting a lack of imagination about alternative models of reward distribution. John Piper agreed to accompany Mitchell on his third expedition in exchange for being clothed, fed and given a horse. ${ }^{29}$ When Mitchell's fourth expedition returned to Sydney, Yuranigh received a 'small gratuity'.$^{30}$ At the end of the Eyre expedition, Wylie received a weekly government ration of flour and meat as well as $£ 2$ and a medal from the Agricultural Society of Perth. He was also appointed a constable of Albany. ${ }^{31}$ Tommy Windich also became a police tracker and constable, and the time of his death was working on the overland telegraph, positions he probably acquired because of his expedition experience, although they scarcely rank as rewards.

The presentation of breastplates to local Aboriginal 'kings' is well documented and was well understood at the time, as is indicated by the reaction of John Piper. ${ }^{32}$ When Mitchell rewarded Piper with a breastplate, it was inscribed, at Piper's insistence, not with 'King' - he said there were 'too many kings already' - but with 'Conqueror of the Inland'. ${ }^{33}$ Jackey Jackey, celebrated survivor of Edward Kennedy's ill-fated 1848 expedition, also received a breastplate and a government gratuity. Uniquely, Jackey Jackey's breastplate was solid silver. The inscription read:

Presented by His Excellency Sir Charles Augustus Fitz Roy K.H., Governor of New South Wales, to Jackey Jackey, An Aboriginal Native of that Colony, In testimony of the fidelity with which he followed the late Assistant Surveyor E.B.C. Kennedy, throughout his exploration of York Peninsula in the year 1848; the noble daring with which he supported that lamented Gentleman, when mortally wounded by the Natives of Escape River, the courage with which, after having affectionately tended the last moments of his Master, he made his way through hostile Tribes, and an unknown Country, to Cape York; and finally the unexampled sagacity with which he conducted the succour that there awaited the Expedition to the rescue of the other survivors of it, who had been left at Shelbourne Bay. ${ }^{34}$

27 Leichhardt 1847, Appendix.

28 Thomas 2015: 124.

29 Baker 1993: 17.

30 Anon 1967.

31 West Australian, 25 June 1941: 8.

32 See Troy 1993; McCarthy 1952.

33 Mitchell 1839: 338-339 quoted in Baker 1998: 45. See also Baker 1993.

34 [Silver breastplate] Presented by His Excellency Sir Charles Augustus Fitz Roy K.H., Governor of New South Wales, to Jackey Jackey ..., item description, State Library New South Wales, 143.119.202.10/item/ itemDetailPaged.aspx?itemID $=446737$. 
The breastplate was displayed in the Australian Museum in the 1860s, presented not by Jackey Jackey or his family but by the governor. ${ }^{35}$ Jackey Jackey was particularly celebrated because his presence at Kennedy's death provided a highly sentimentalised and idealised image of the relationship between explorer hero and Aboriginal companion (see Nugent in this volume).

The inadequacy of rewards was recognised by some at the time. Edward Read Parker, who had himself explored and then settled in the area around Dangin, 160 kilometres east of Perth, wrote a letter to the West Australian Times shortly after the return of Forrest's 1874 expedition. He commented perceptively that the 'laudations and presents, and the greetings shown towards Forrest and his party, will shortly become things of the past ... when the quiet ploddings of the every-day life are again resumed by each individual'. He argued that it was the duty of the government to give 'a small and lasting pension, that is, for life, to Tommy Windich "in recognition of his valuable and long tried service in so many expeditions"'. He challenged readers to "name an expedition into the interior without naming Tommy Windich as one of the party'.$^{36}$

\section{Portraits}

While Aboriginal people appear as exotic background scenery in early paintings of Australia, individuals, including guides, also had their portraits painted. Many explorers' journals were illustrated with portraits of their participants and this included the Aboriginal guides. Artists depicted them in various ways but generally acknowledged the individuality of the guides themselves.

Leichhardt's published journal (1847) included distinctive personal portrayals of Charley Fisher and Harry Brown. ${ }^{37}$ They are dressed in plain shirts and have individual expressions - contemplative, intelligent and, in Fisher's case, sad. These are not caricatures, nor are they cheap exploitations of indigeneity. They are respectful portraits and could be seen as depicting these two men as (unhappily) trapped in European disguise, with no recognition of their cultural difference. Whatever the interpretation, the artist's depiction of Leichhardt's Aboriginal guides appears sympathetic, in keeping with Leichhardt's positive, albeit tempestuous, relationship with the two men. ${ }^{38}$

\footnotetext{
35 Sydney Morning Herald, 1 October 1868: 5.

36 West Australian Times, 29 December 1874: 3.

37 'Charley [and] Harry Brown' in Leichhardt 1847.

38 Clarke 2008: 97; Kennedy 2013: 159-162. On Leichhardt's second expedition in 1847, Harry Brown was acknowledged for a time as de facto commander, Kennedy 2013: 161.
} 


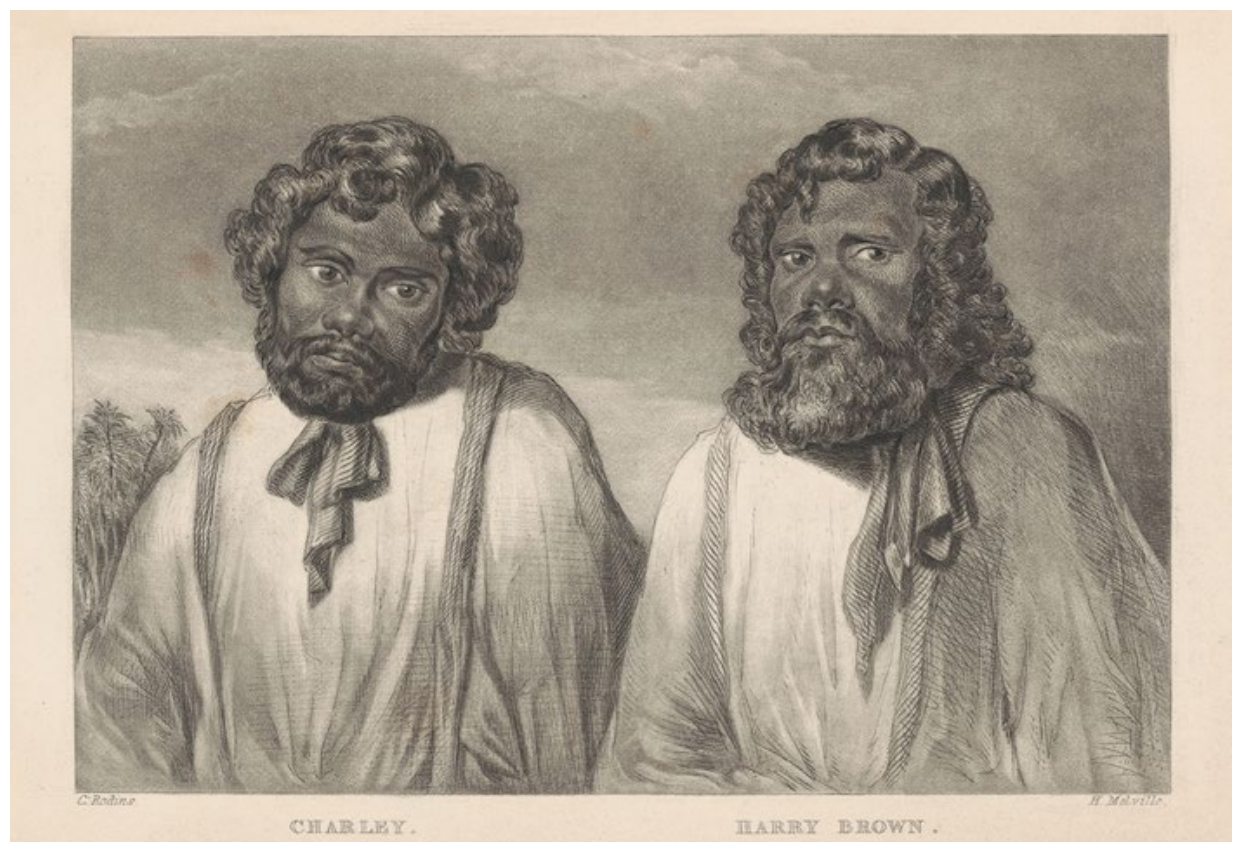

Figure 3.1 Charley Fisher and Harry Brown, guides on Leichhardt's expedition, 1844-45.

Source: Ludwig Leichhardt, Journal of an Overland Expedition in Australia, from Moreton Bay to Port Essington, during the years 1844-1845, T\&W Boone, London, 1847. Courtesy National Library of Australia.

Aboriginal guides were also often subjects of portraits outside the published journals. While exoticism was part of their appeal to prospective buyers, these were very definitely pictures of individuals who were important to European society. After Mitchell's 1836 expedition, John Piper was much feted in Sydney. W.H. Fernyhough included Piper, 'the native who accompanied Major Mitchell in his expedition to the interior of N.S.W.', in his series of 12 lithographic silhouette portraits of Aborigines. Fernyhough and his publisher John Austin recognised Piper's marketability. He was depicted in his trademark costume, having become a recognisable figure 'strutting about Sydney [in] a red coat and cocked hat with long white feathers' ${ }^{39}$ As Elisabeth Findlay notes, Piper's deliberate swagger in such conspicuous clothing suggests he was consciously cultivating his celebrity. Piper reappeared in Fernyhough's portrait of Thomas Mitchell, who is shown holding the artist's silhouette of Piper. While this might merely be indicating the close relationship between the two men, or just be clever cross promotion, Findlay has drawn attention to the significant timing of the portraits, with the second appearing for sale when Mitchell was attempting to blame Piper for Aboriginal deaths on the expedition. ${ }^{40}$

39 Sydney Gazette and New South Wales Advertiser, 20 December 1836: 2; 'Piper' at National Portrait Gallery, www.portrait.gov.au/site/collection_info.php?searchtype=advan\&searchstring $=\&$ irn $=52 \& a c n o=19$ 99.23.2\&onshow=.

40 Findlay 2013: 20-21. 


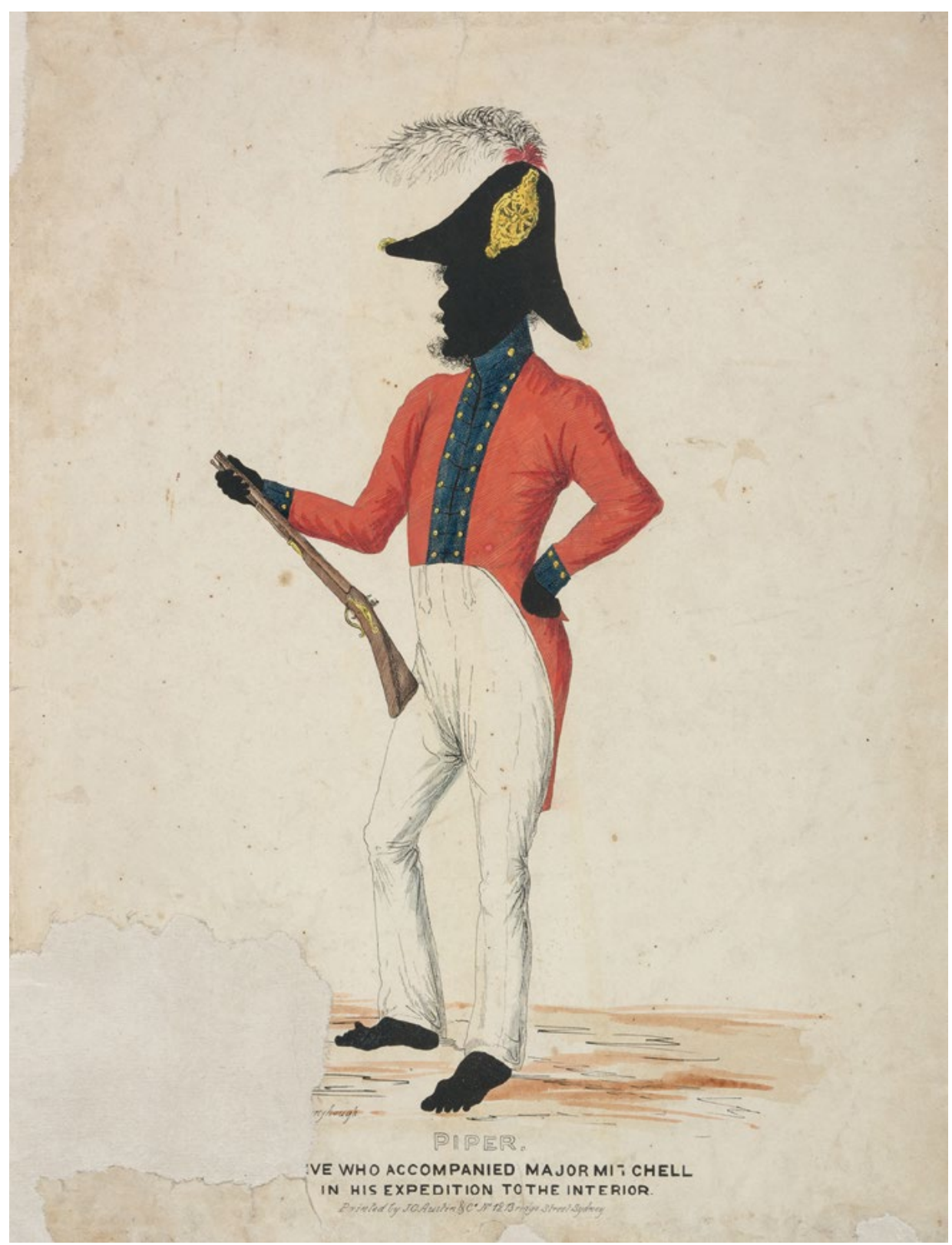

Figure 3.2 W.H. Fernyhough, 'Piper. The Native who accompanied Major Mitchell in His Expedition to the Interior', c. 1836.

Source: Album of portraits, mainly of New South Wales officials, c. 1836, PXA 617, Mitchell Library, State Library of New South Wales. 


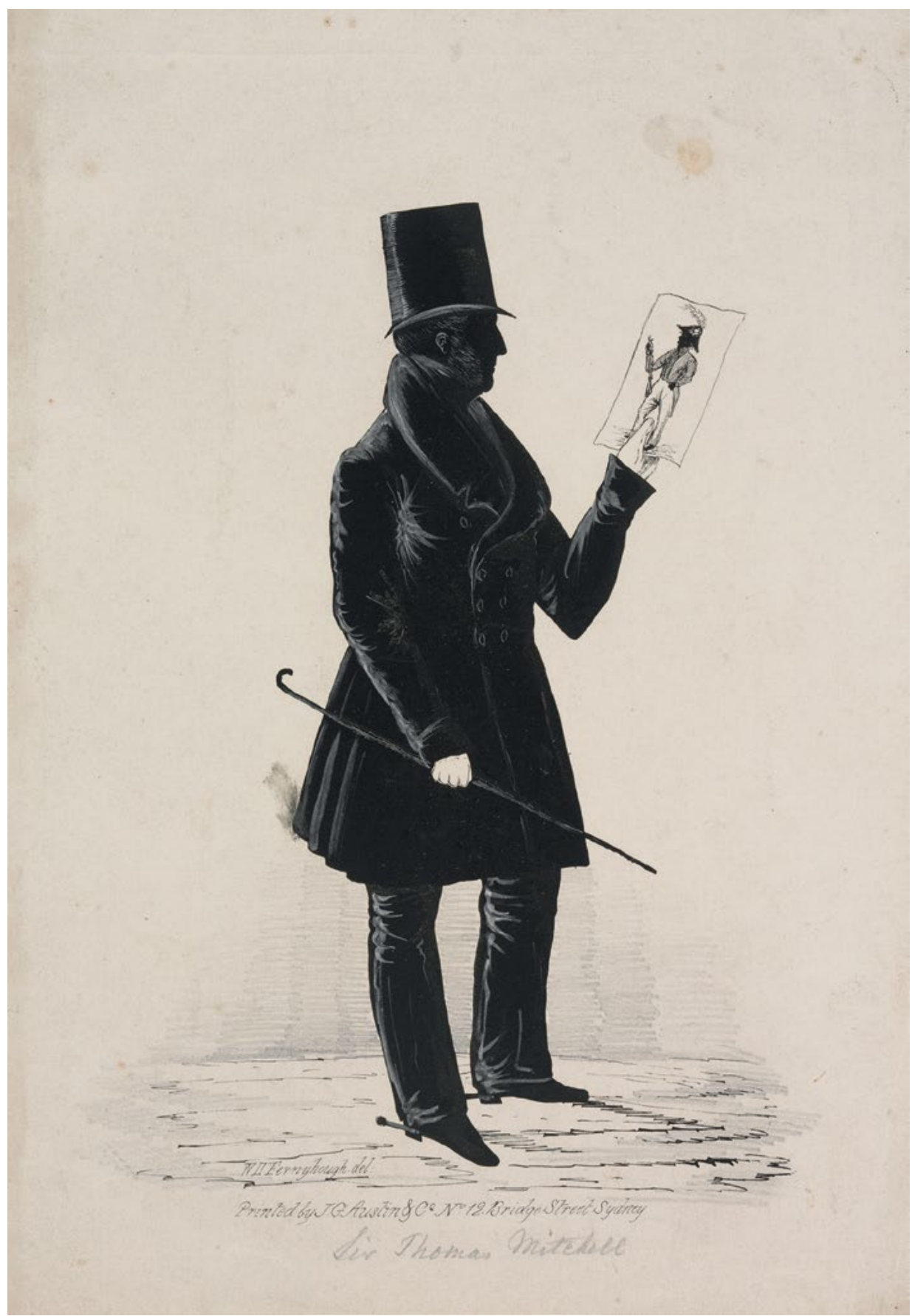

Figure 3.3 W.H. Fernyhough, 'Sir Thomas Mitchell', c. 1836.

Source: Album of portraits, mainly of New South Wales officials, c. 1836, PXA 617, Mitchell Library, State Library of New South Wales. 
Jackey Jackey's fame was reinforced by the 1849 lithographic portrait by Charles Rodius, who had already produced two sets of lithographs of Aboriginal identities. Identified as 'Jackey Jackey - Expedition of Kennedy 1849', he was portrayed as a steadfast, contemplative man, shirtless but wearing trousers. Kennedy's death meant that there was no sense of celebration but instead of melancholy and loss. When the NSW Legislative Council commissioned a monument to Kennedy in St James' Church, Sydney, it included a bas-relief of Jackey Jackey holding Kennedy in his dying moments and a tribute to the guide:

\section{JACKEY JACKEY}

WHO WAS MR. KENNEDY'S SOLE COMPANION IN HIS CONFLICT WITH THE SAVAGES,

\section{AND THOUGH HIMSELF WOUNDED}

\section{TENDED HIS LEADER WITH A COURAGE AND DEVOTION WORTHY OF REMEMBRANCE,}

\section{SUPPORTING HIM IN HIS LAST MOMENTS,}

\section{AND MAKING HIS GRAVE ON THE SPOT WHERE HE FELL.}

This sense of loss was repeated in the major 1865 painting of 'The Death of Kennedy' by Eugene Montague Scott. It was regarded as 'the best of all' his paintings and attracted 'considerable notice' when exhibited in 1873. ${ }^{41}$ The painting was bought by a Sydney café owner for display in his establishment, clear evidence of the popularity of heroic explorers at that time. The Sydney Morning Herald approved of the painting and of Jackey Jackey, 'whose homely name has, in New South Wales, since that time, been permanently associated with the idea of manly courage, gentle affection and dog-like fidelity'. ${ }^{42}$ The high praise of 'manly courage', normally a quality reserved for white colonial males, was somewhat undercut by the attribution of 'dog-like fidelity'. Rodius's portrait had been similarly well-received, although the comment in Bell's Life in Sydney underlined how these guides were seen as exceptional; 'the intelligence of his countenance, (so unlike the mass of Aborigines,) is very happily caught'. ${ }^{43}$

41 Sydney Morning Herald, 17 April 1873: 5.

42 Sydney Morning Herald, 21 September 1865: 10.

43 Bell's Life in Sydney, 24 March 1849: 2. 


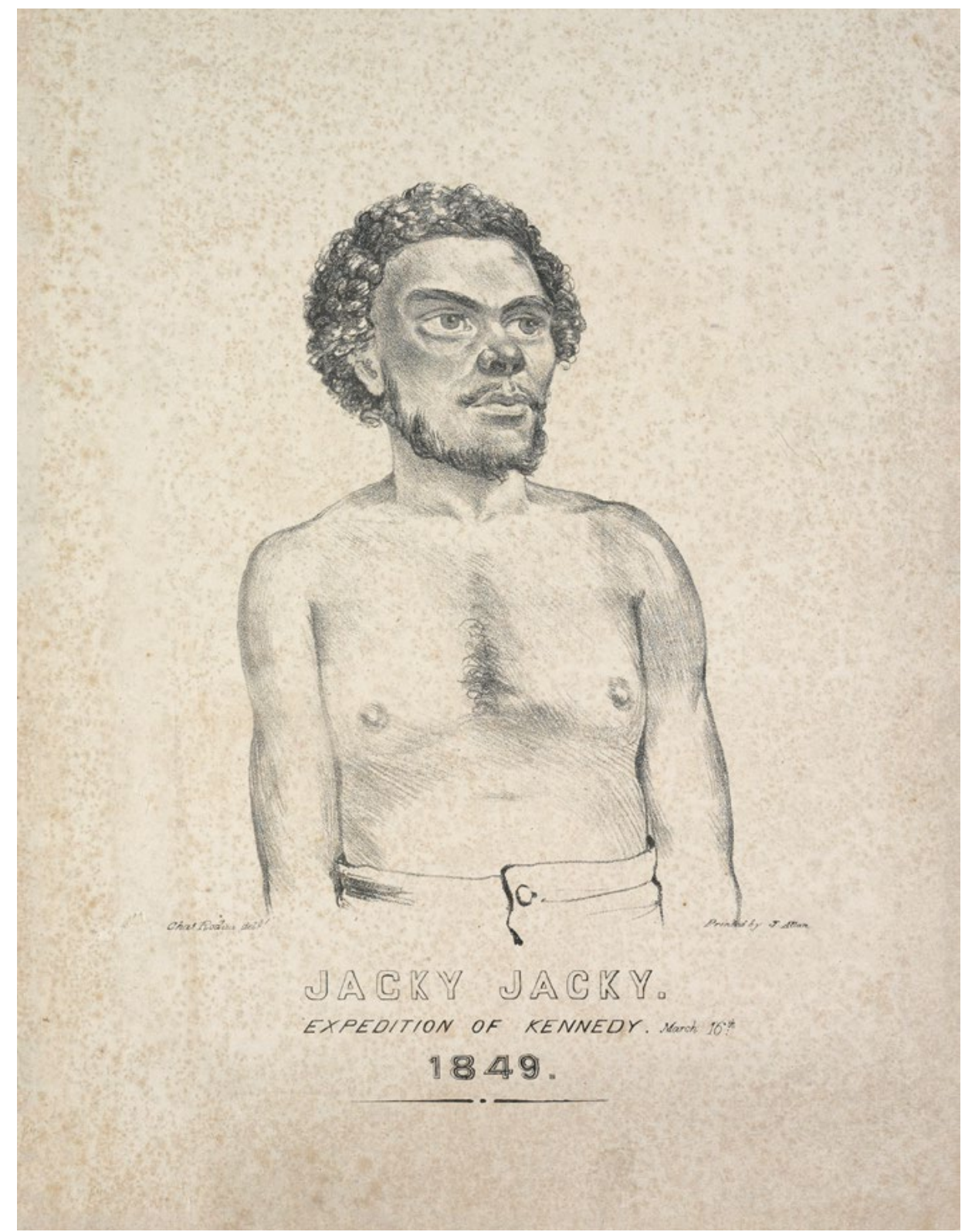

Figure 3.4 Charles Rodius, 'Jacky Jacky, Expedition of Kennedy, March 16th 1849'.

Source: Collection of portraits, predominantly of Aborigines of New South Wales and Tasmania, c. 1817-1849, SAFE/PXA 615, Mitchell Library, State Library of New South Wales.

Less racially charged are the photographic studio portraits of the Forrest brothers' expeditions. In these the Aboriginal and European men are grouped together. In one, from 1874, Alexander and John Forrest are seated in front, 
clearly leaders of the expedition. Behind them, all in a row, are Tommy Pierre, Tommy Windich and two European participants. In another photograph of an earlier expedition in 1871, Jemmy Mungaro, an Aboriginal guide, squats beside Alexander Forrest and James Sweeney, who are seated on chairs. Behind them stand two other European participants and Tommy Windich. In a publicity photograph from the 1869 expedition in search of Leichhardt's remains, Tommy Windich is at the centre of the picture. He is posed on bended knee, flanked by Malcolm Hamersley and John Forrest, who are standing; but Windich is very much the centre - the focus - of the portrait. ${ }^{44}$

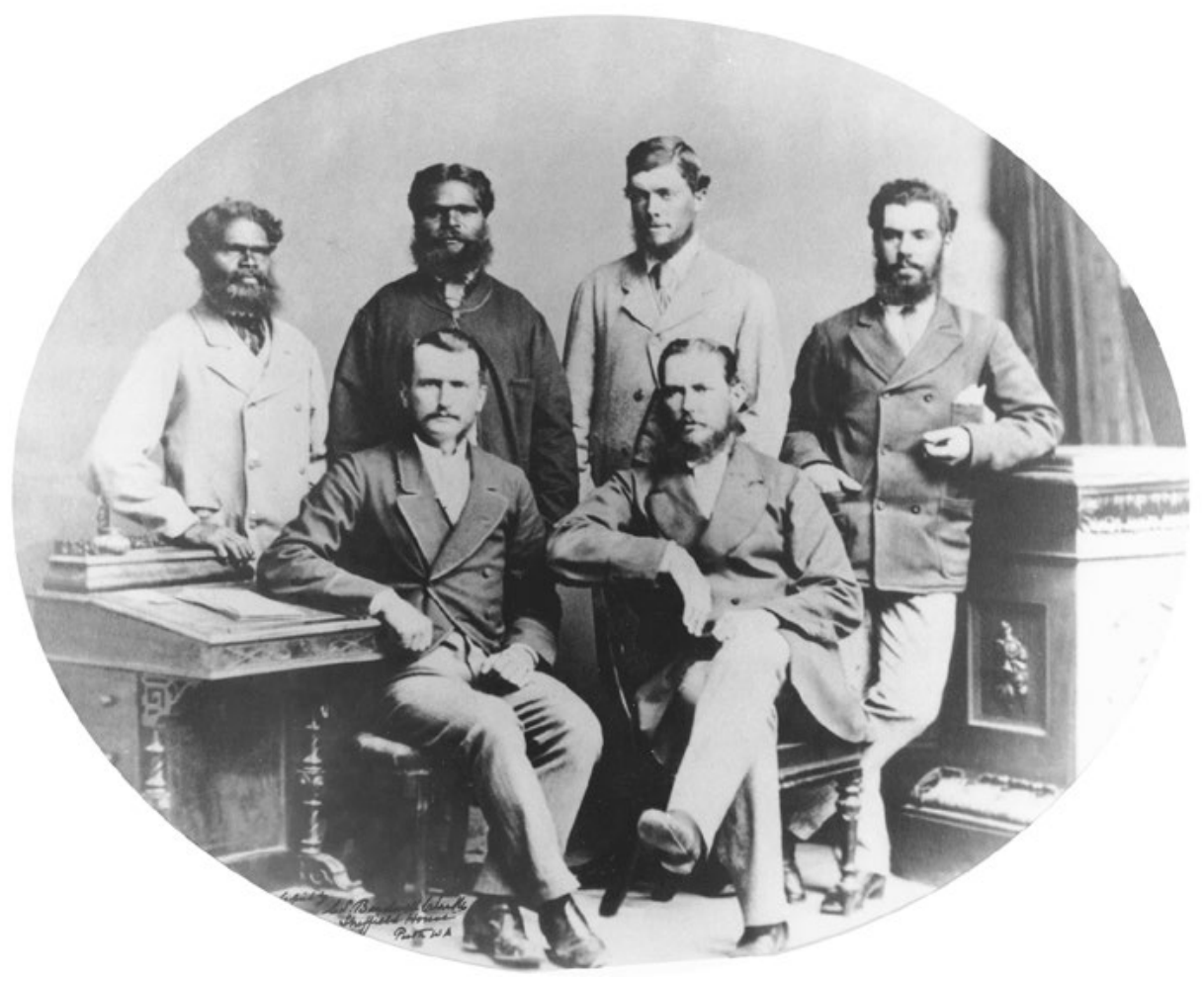

Figure 3.5 'Forrest expedition exploring party, 1874'.

Left to right, back row: Tommy Pierre, Tommy Windich, James Kennedy, James Sweeney; front row: Alexander Forrest, John Forrest.

Source: State Library of Western Australia, 004541D.

44 'Malcolm Hamersley, Tommy Windich and John Forrest, part of an exploring expedition in search of the remains of the late Dr Leichhardt and party', 1869, National Library of Australia, picture 174393417. These portraits are in sharp contrast to, for example, African explorer Henry Stanley's use of his boy guide Kalulu. Stanley took Kalulu to London and he is included in several photographic portraits of the white explorer, as much an accessory as the gun, spear and shield also included. This is emphasised by the possessive title of Stanley's later pamphlet 'My Kalulu'. See Kennedy 2013: 171-173. Stanley created a celebrity for Kalulu because it augmented his own status. 


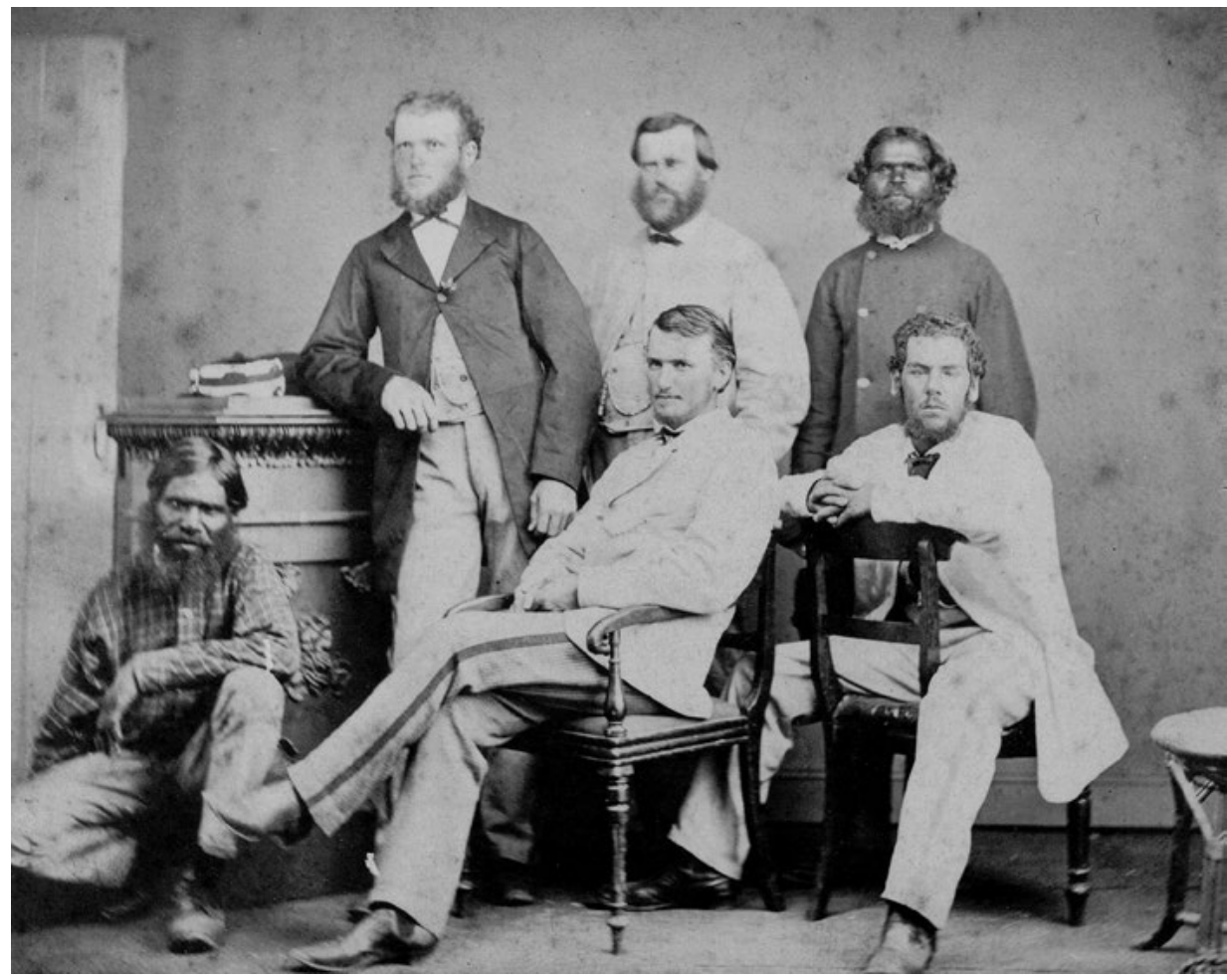

Figure 3.6 'Six members of the exploration party to the eastward and southward of Hampton Plains, led by Alexander Forrest', 1871.

Left to right, standing: Richard Burges or Hector McLarty, George Monger, Tommy Windich; sitting: Jemmy Mungaro, Alexander Forrest, James Sweeney.

Source: State Library of Western Australia, 001297D.

Images of Aboriginal guides continued to be produced and to sell well into the twentieth century. In the plethora of images depicting stages of the Eyre expedition, Wylie was usually included. And in January 1919 the Northern Herald contained portraits not only of Palmerston but also of Pompo. The Cairns Post noted that these would 'appeal to old-timers'. ${ }^{45}$

There is a notable exception to artists' recognition of individuality in their Indigenous guide subjects. That this exception is a woman is perhaps indicative of the way in which this was very much a masculine world. In Mitchell's journal, Turandurey and her daughter, who is on her shoulders, are shown as part of the environment 'with the scenery on the Lachlan'. Facing away from the artist, as if observing the countryside, the woman and girl are naked. This is less about the individual than the idyllic. 


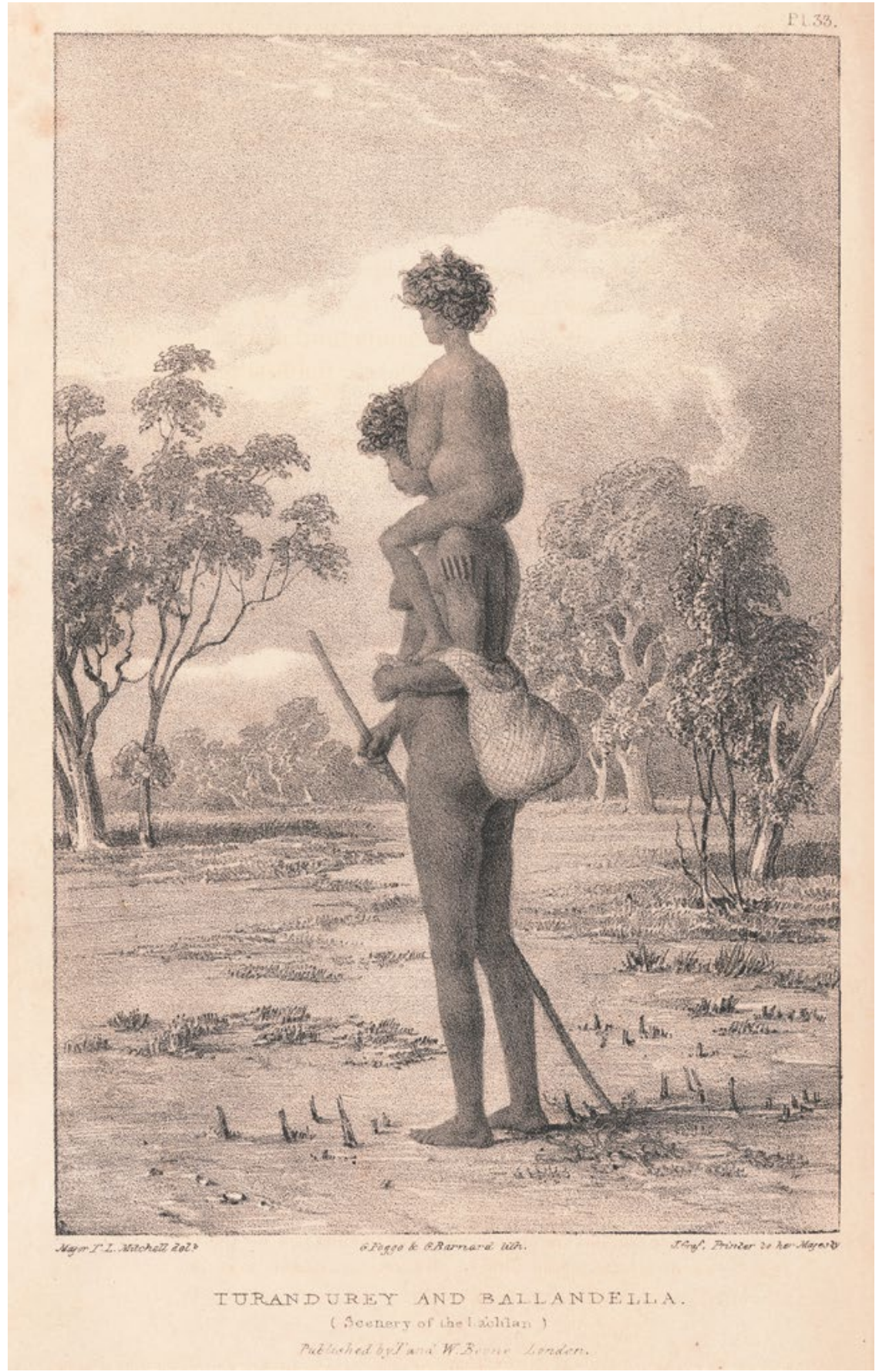

Figure 3.7 Thomas Mitchell, 'Portraits of Turandurey (the female guide) and her child Ballandella, with the scenery on the Lachlan (10th May 1836)'.

Source: Major T.L. Mitchell, Three Expeditions into the Interior of Eastern Australia, T. and W. Boone, London, 1839. Courtesy National Library of Australia. 


\section{Deaths, burials and obituaries}

While some Aboriginal guides became police trackers, their celebrity did not necessarily convert into a better life. Indeed their minor celebrity status was possibly a hindrance to their returning to their own communities, and yet it was never enough to lead to acceptance in white society. Perhaps Tommy Dower, who was the third 'Tommy' to accompany the Forrest brothers, had the most notable later life, becoming something of a media personality in the 1880s. The Inquirer reported that Dower 'wishes to know how it is he has not been remunerated either in money or land' for his services on the exploring trip to Port Darwin. ${ }^{46}$ It is difficult to tell whether this story was instigated by Dower or the Inquirer itself, but Geoffrey Bolton suggests Dower knew how to make his concerns noticed by exploiting his position as an explorer's guide, his value as entertainment and his status within Aboriginal society. He was known as the 'King of West Australia' when he died in 1895, 20 years after his two Aboriginal companions.

Most of the others were left in limbo and died earlier deaths than might have been expected. Moowattin's fate was an extreme example. In 1810 Caley took him to England, where he was paraded around 'in the pink of fashion', but then he returned alone to Sydney, where he was hanged for the rape of a white girl in 1816. ${ }^{47}$ Mokare, Yuranigh, Jackey Jackey, Tommy Windich, Tommy Pierre, Pompo and Dick Cubadgee all died within six years of their exploring exploits. Wylie was still alive seven years after his moment of fame but then disappeared from the (white) public view.

Dying so soon after acquiring celebrity status, these men often inspired obituaries in the local press. In the case of Jackey Jackey, who died after falling into a campfire, apparently drunk, there was a sense of disappointment that such a 'faithful guide' had succumbed to the evils of drink. The fate of Jackey Jackey was seen as being particularly poignant, as he was a hero, yet ultimately unsurprising. Others died more respectable deaths. Expedition leaders often took the opportunity to comment on the loyalty of their erstwhile companions. Upon Tommy Windich's death in 1876, John Forrest wrote to the Inquirer that he had 'lost an old and well-tried companion and friend' ${ }^{48}$ Four years later he used the same phrase when Tommy Pierre died, telling the Herald 'I feel that

46 Inquirer, 22 November 1882 in Bolton 1988: 80.

47 Smith 2005

48 Inquirer and Commercial News, 15 March 1876: 3. 
I have lost an old companion and friend'. ${ }^{49}$ A year after Pompo died, Palmerston recorded in the Brisbane Courier that the loss of his 'faithful little follower' was 'irreparable' and

plunged me in great misery. Even now it is with an overwhelming sense of grief and with swimming eyes I copy these lines. It is not in me to express how much this little aborigine had endeared himself to me by his bright intelligence and fidelity. ${ }^{50}$

The sentimentality was heightened by exaggerating Pompo's youth. Given Palmerston's bloody reputation with regard to Aboriginal people, his public expression of grief for Pompo underscores the way in which guides could be considered quite separately from the rest of the Indigenous population.

Expedition leaders also publicly recognised their Aboriginal guides by arranging formal commemorations, often contributing to their burial and gravestone. Palmerston was reported as having had a tombstone erected on Pompo's grave. ${ }^{51}$ Yuranigh died in his own country and was buried by his community near Molong in New South Wales. His grave was fenced at government expense and Mitchell paid for an adjacent monument, which was inscribed:

To

$$
\begin{gathered}
\text { Native Courage } \\
\text { Honesty and Fidelity. } \\
\text { Yuranigh } \\
\text { who accompanied the } \\
\text { expedition of discovery } \\
\text { into tropical Australia in } \\
1846 \\
\text { lies buried here } \\
\text { according to the rites } \\
\text { of his countrymen } \\
\text { and this spot was } \\
\text { dedicated and enclosed } \\
\text { by the } \\
\text { Governor General's authority } \\
\text { in } 1852 \text {. }
\end{gathered}
$$

49 Herald (Fremantle), 22 November 1879: 3.

50 Brisbane Courier, 27 September 1883: 2.

51 The Queenslander, 22 January 1881: 109. 
Mitchell, in an unusual moment of modesty, did not include his own name on the tombstone. Twenty years later, the Forrest brothers saw value in emphasising their patronage of their guides. They paid for Windich's tombstone, on which was inscribed the words:

Erected by
John and Alexander Forrest
in Memory of
Tommy Windich,
Born near Mt Stirling 1849
Died at Esperance Bay 1876.
He was an aboriginal native of Western Australia,
of great intelligence and fidelity, who accompanied them on EXPLORING
EXPEDITIONS
into the interior of Australia, two of which were from
PERTH to ADELAIDE.
Be ye also ready!

When Tommy Dower died in 1895 he was buried in East Perth cemetery, the only Aboriginal person to be interred there. His tombstone and burial were organised by the Aborigines Protection Board, although Bolton suggests the Forrest brothers were instrumental. Billy Noongale was another of John Forrest's guides, described on his tombstone in 1905 as 'one of his faithful companions'. As Bolton aptly summed up, the Forrests 'were at least punctilious in ensuring that their Aboriginal offsiders were given decent funerals' ${ }^{52}$ The Forrest family continued that sense of responsibility: in 1950, Alexander's son John Forrest paid $£ 15$ for preservation work on Tommy Windich's grave in Esperance. ${ }^{53}$

But the most remarkable example of an explorer's involvement in the burial of his guide was also one of the earliest. Mokare, an experienced guide, went exploring in Western Australia with Alexander Collie in 1830. When Mokare died in June 1831, his family chose a burial site on Alexander Collie's property. Four years later, Collie died. At his specific request he was buried next to Mokare. In 1840 Collie's bones (or bones assumed to be Collie's) ${ }^{54}$ were disinterred and reburied in the new Albany cemetery. Mokare was apparently forgotten, although in Aberdeen, Scotland, Alexander Collie's brother, George, named his house 'Morkeu' after his brother's friend. This recognition and the intensity of friendship and feeling suggested by Alexander Collie's burial instructions were unique; unlike the flowery phrases and declarations of other explorers, these

52 Bolton 1988: 82.

53 Kalgoorlie Miner, 18 March 1950: 4.

54 Green 2005. See also Bladon et al. 2011. 
were actions that cannot be misinterpreted. Perhaps at this stage of European colonisation in Western Australia explorer-guide relations had not yet settled into formal separation of patron and patronised. By the same token, the official reburial of Collie but not Mokare nine years later is similarly telling - suggesting that Collie's personal wishes were less important than the need to have such a celebrity as Collie as the first occupant of the new town cemetery. Ironically, in spite of local citizens' concerns to celebrate Collie, by 1935 his grave had vanished and his importance lost in local memory. ${ }^{55}$

This celebration of a particular set of Aboriginal guides, in the heyday of exploration - through naming places, acknowledgements in print, on public occasions and after death - seems odd in a society that was also brutally dispossessing Indigenous people, dismissing them as primitive savages or children; a society that was, at the same time, actively promoting the ideal of the lone explorer as hero. One explanation for this conundrum lies with that lone explorer himself.

It is striking that in most of these cases the expedition's leader seems to have taken the initiative in publicly acknowledging the contribution of their Indigenous 'professional' guides. On the face of it this seems to go against their self-interest in identifying with the explorer myth. But by emphasising their relationship with these individuals, these explorers were positioning themselves as intermediaries between the cultures, as adept at engaging with Indigenous cultures. It positioned them as people who can speak for and inspire loyalty from 'the other'. Sometimes, it is true, they emphasised the childlike 'faithfulness' of their companions, but they also publicly appreciated their skills. It is also probably significant that some of the most definite in their praise of specific Aboriginal companions - Mitchell, Palmerston and Warburton - were also criticised for being too ready to use force against Indigenous people. Yet we should not discount the importance of genuine affection and regard explorer and guide could have for each other.

This still does not explain the wider public celebrity given to these men. Explorers were heroes whose words carried weight among a respectful public. The guides were also colourful characters, providing an exotic backdrop to the imperial enterprise. Their skills in bushcraft were widely acknowledged. The public was well aware of the dangers of the Australian environment and of the accompanying potential threat from Indigenous people hostile to the spread of European settlement. Guides were 'friendly natives' in a landscape of potential enemies. They appeared to be reassuring, living proof that it was possible to coopt Aboriginal people in European interests. Just as Edward Eyre felt supremely grateful to Wylie for not deserting him in the wake of Baxter's murder, so did 
citizens of small frontier towns sing the praises of such men, perhaps with a sense of relief. The guides were a model for how Australians felt Aboriginal people should be.

\section{A great Australian silence? Forgetting Indigenous guides}

It is clear that recognising the assistance of Indigenous guides was a regular feature of the celebration of exploration in its heyday in the nineteenth century. But subsequently they were increasingly written out of the history of exploration. Part of the explanation for this forgetting lies in the way exploration became part of a national historical narrative. ${ }^{56}$ In a local setting, and for a range of motives, explorers might acknowledge some debt to those who guided them and others might accord some individuals recognition. But in a national story, in which exploration was the origin myth that brought the nation into being, and in which convention required a history of great white men, Indigenous guides were an inconvenience.

The first comprehensive account of Australian exploration was published in 1888 as part of the colonial centenary celebrations, with the support of the New South Wales government and 'under the auspices of the Government of the Australian Colonies'. The somewhat excessively titled The History of Australian Exploration from 1788 to 1888. Compiled from State Documents, Private Papers and the most authentic sources of information was 'a rather formidable volume', according to the Daily Telegraph, but it nevertheless became a popular success. The author was an established journalist, Ernest Favenc, himself an explorer of some note (if not as much as he received from his own pen) who went on to write novels, poetry and short stories. Favenc almost single-handedly created the canon of notable explorers. His inclusions and omissions, peppered with forthright opinions on their achievements, their effectiveness and the quality of their bushcraft (compared implicitly with his own), were definitive. As a late romantic, he focused on the individual explorer as hero, in the belief that 'the great charm of Australian exploration' was 'the spectacle of one man pitted against the whole force of nature' ${ }^{57}$ In his account there was little room for recognising the contribution of guides (or indeed of any other members of the expedition). Among many others, Moowattin, Mokare, Piper, Yuranigh, Pompo and Cubadgee received no mention, and those that did were depicted as the possessions of their masters. Wylie was only seen as important because he did not participate in Baxter's murder, after which 'Eyre proceeded on his journey', and Windich figured only as the 'black

56 Reynolds 2000: 18-21.

57 Favenc 1888: v-vi. 
boy' whom Forrest acknowledged in the naming of Windich Springs. Ernest Giles's 'black boy' Tommy and the 'pompous' Warburton's 'black boy, Charley' were recognised as finding water at crucial times, and Eulah received a mention as the Jardines' 'most-trusted black boy'. Various other anonymous 'black boys' were mentioned as accompanying other expeditions, including Favenc's own explorations, but their actual contribution was ignored. Occasionally they provided an opportunity for Favenc's malicious humour. Leichhardt and 'the black boy, Charlie, managed to get lost for two or three days, a faculty which apparently most of the party happily possessed' ${ }^{58}$ Turandurey also became an opportunity for humour in the account of Mitchell's punitive raid on the Aborigines who had been harassing his progress, in which seven were killed. Turandurey, unnamed except as 'the black boy's gin', had been left as

the sole protector of the drays, and equipment. On his return, the Major found her standing erect at the head of the leading horse, with a drawn sword over her shoulder.

Her appearance was, above all, both laughable and interesting. She was a tall, gaunt woman, with one disfigured eye, and her attitude, as she stood there with the naked weapon in her hand, faithful guard of all their belongings, was a picture that Mitchell did not soon forget. ${ }^{59}$

The one exception to brief or 'humorous' mentions was Jackey Jackey. He was still merely 'the black boy Jacky-Jacky' or 'a naked blackfellow', but Jackey Jackey's own well-publicised account of the last days of Kennedy was given at length:

The one brightening touch in the whole gloomy picture is the simple devotion shown by poor Jacky: 'He then fell back and died, and I caught him as he fell back and held him, AND THEN I TURNED ROUND MYSELF AND CRIED,' was the funeral oration over the brave and unfortunate Kennedy. ${ }^{60}$

Favenc's exclusion of a meaningful Indigenous contribution in his story of exploration reflected a far more deliberate social Darwinism than many of his peers. A later novel, The Secret of the Australian Desert (1895), a fictional account of Leichhardt's disappearance among a 'depraved, bloodthirsty cannibalistic tribe of savages', was a warning to Australians that mixing too closely with Aboriginal people would lead to the white race's degeneration. ${ }^{61}$ In addition, he explicitly argued that Indigenous knowledge was of little assistance to Australian exploration on the grounds that 'the blackfellow of Australia' was

58 Favenc 1888: 135, 262, 266, 193, 257, 242, 153.

59 Favenc 1888: 112-113.

60 Favenc 1888: 171, 169, 172-173.

61 Anon 2010. 
circumscribed by the boundaries of his own country, so information he was able to impart was, as a rule, meagre and misleading, and without any good result in the way of assistance to the explorer' ${ }^{62}$

Favenc's interpretation dominated explorer historiography and heralded the great Australian silence' for the next 80 years, when Aboriginal people had little place in a national history. Nevertheless, as a number of historians have noted recently, this was not necessarily true at a local or regional level. ${ }^{63}$ The silence could be broken by an expedition anniversary, or an occasional historical feature in a local newspaper, usually prompted by a zealous local historian or an enthusiastic commemoration committee. Aboriginal guides were being recognised, still within a framework of 'faithful henchman', ${ }^{64}$ but recognised nonetheless, and often to a greater degree than the other European members of the party. Recognition was easier when there was already a site, such as a grave, that could be a focus. In 1908 the state government renovated Yuranigh's grave and replaced the headstone. ${ }^{65}$ In 1935 there was a 'pilgrimage' to the site by the local historical society, and in 1952 the Orange Historical Society organised a similar excursion. ${ }^{6}$ A creek near Molong and a county in Queensland were also named after Yuranigh.

When Alexander Collie was rediscovered and memorialised in Albany in 1935 on the anniversary of his death, a local Albany historian, Robert Stephens, began to take an interest in Mokare, requesting information about the whereabouts of his grave in the local paper. He also took an interest in Eyre's companion, Wylie, another local. Ten years later, Stephens publicly pushed for recognition of those he called 'Black Helpers' ${ }^{67}$ In 1946 Wylie Crescent appeared at the same time as Mokare Park was gazetted, and the following year, further afield, Wylie Head and Wylie Bay were named by the surveyor general. ${ }^{68}$

For over a century explorers themselves were perhaps the most acceptable face of Australian history for the establishment. The authorities, who often deplored the popular interest in convicts and bushrangers, encouraged the celebration of explorers, along with pioneer settlers, because they were respectable. Similarly, Aboriginal guides could be considered acceptable in ways that other Indigenous people - fringe dwellers, cattle-killers and 'myalls' - were not. The guides

\footnotetext{
62 Favenc 1888: 286.

63 Healy 1997; Curthoys 2001; Nettlebeck and Foster 2010; Griffin-Foley 2011.

64 This term was applied to Jackey Jackey by L.M.R., a correspondent to the Sunday Mail, 17 July 1932: 3. It was also used for 'Jacky, who was for years [Tom] Petre's faithful henchman', who is buried at Maroomba in Queensland, in an article in The World's News, 10 April 1948: 22.

65 Evening News (Sydney), 24 August 1908: 8.

66 Molong Express and Western District Advertiser, 23 March 1935: 8; 28 April 1950: 1.

67 Albany Advertiser, 15 July 1935: 6; 3 December 1845: 8. They were also represented as 'black helpers' in the West Australian, 4 April 1936: 18.

68 West Australian, 5 March 1947: 5.
} 
continued to represent a success story of peaceful coexistence, as 'faithful' and 'loyal' servants to the various famous white explorers. They were the epitome of cooperation and assimilation. In 1934 Alexander Petrie Campbell, a Congregational minister, wrote to the Sydney Morning Herald applauding the public's enthusiasm for explorers, suggesting that 'with the rounding of the century we seem to have awakened a proper interest in the development of our land'. But the purpose of the article was to draw attention to the 'quality and worth' of Aboriginal people, by pointing to the role of the Aboriginal participants on the expeditions. Underpinning his argument was the fact that 'Our early explorers were not slow to recognise the partnership of the aboriginal in the work'. His choice of the word partnership is uncharacteristic for the era, although the title of the piece was more typical: 'Yuranigh, Nature's Gentleman'. ${ }^{69}$

\section{Rediscovering Indigenous explorers}

In the last third of the twentieth century, academic historians began to write Indigenous Australians into what had been a predominantly white history. In popular culture, in the development of school curricula, in tourism and in various forms of public commemoration, Aboriginal history also became more visible. In the case of explorers' Aboriginal companions, the emphasis was initially on their role as faithful servants, a continuation of their depiction in popular culture in the 1930s. For historians in a post-colonial age, explorers were becoming problematic - rather than being respectable celebratory historical figures, they were part of an imperial invasion. Their guides could be seen as collaborators, with questions asked about their motivation in assisting the European imperial project. Others emphasised the guides' role as independent agents. Ironically, this emphasis on their agency, skill and knowledge of their country, along with explorers' acknowledgement of their reliance upon them, was a way of returning explorers themselves to a recast version of Australian history.

The changes can be seen in a 1986 school text: in accounts of specific expeditions we learn of Wylie's 'loyal service' to Eyre and of Kennedy's 'faithful Aboriginal companion, Jacky Jacky', but a later chapter discusses explorers' relations with Aboriginal people and points to their dependence on the skills of their guides. ${ }^{70}$ It is even clearer in the differences in the style and tone of entries for 'indigenous guides' in the Australian Dictionary of Biography $(A D B)$. The entries for Wylie, Yuranigh and Jackey Jackey were written in 1967, Tommy Windich appeared in 1976, and Cubadgee, Mokare and Broughton in 2005, part of the millennium 'catch-up' of entries for individuals previously not considered as material for a

69 Sydney Morning Herald, 15 September 1934: 11.

70 Foster 1986: 87, 90, 105. 
national dictionary of biography. The entry for Jackey Jackey (1967) refers to an attack by 'blacks' and the loyalty and attachment of Jackey Jackey to his 'master'. ${ }^{71}$ Wylie (1967) was described as 'sulky and disobedient' when food supplies became low, because his 'good temper largely depended on prodigious meals rich in protein'. ${ }^{72}$ Earlier $A D B$ entries focusing on expedition leaders either ignored the guides ${ }^{73}$ or depicted them in similar ways: in the 1966 entry for Collie, Mokare was his 'faithful exploring companion' ${ }^{74}$ These depictions of guides as childlike or devoted are not found in the later entries. Philip Jones insisted that Cubadgee (2005) was 'not simply "Lindsay's boy"', while the entry for Mokare (2005) similarly avoided perpetuating 'loyal native' stereotypes. ${ }^{75}$ In addition, more attention was paid to their place within the Aboriginal world, increasing the sense of their more fully rounded individuality.

In the 1980s and 1990s there was a surge of interest in historical commemoration generally, and the shift in approach, giving some recognition to Indigenous guides as independent agents, carried over into a range of civic activity. Local historians once again led the way, sometimes with an eye to the tourist potential of a guide's distinctive historical associations with a particular region. Streets were named, sculptures were commissioned and interpretative panels began to litter civic parks. A monument to Warburton erected in 1989 not only acknowledged Charley but also the expedition's two Afghan men, who were named:

\section{PETER EDGERTON WARBURTON}

Left the known here for the unknown

On April 18th 1873

With his son Richard, J.W. Lewis, Dennis

White, Charley, Sahleh and Halleem.

After suffering many privations, hunger and thirst crossing the Great Sandy

Desert the party reached Roebourne W.A.

with no loss of life on Jan. 26th. 1874

Erected by his relatives

To commemorate the 100th Anniversary of

His death November 5th 1889

The Europeans were still listed first, but interestingly the order of precedence for the Afghan and Aboriginal members was reversed from what it might have been in the nineteenth century.

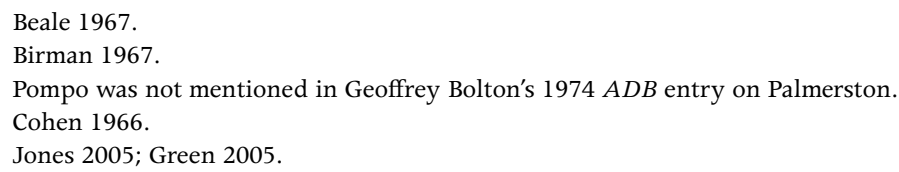


The 1991 sesquicentenary of the Eyre expedition prompted a number of memorials. It was not coincidental that hundreds of 'grey nomads' and other tourists crossing the Nullarbor were now following Eyre and Wylie's route. Explorers do not generally generate popular tourist attractions - their impact on the land is too ephemeral - but when there is little else, a monument can attract tourist interest and town councils along the route were aware of the fact. The town of Eucla, near the start of the journey, acquired a monument to commemorate the entire party. In recognising the contribution of the Indigenous guides alongside the Europeans, there was no mention of Baxter's subsequent murder by Joey and Yarry. The inscription simply reads:

EDWARD JOHN EYRE, BAXTER, WYLIE, JOEY, YARRY.

On 11 March 1841

camped in this vicinity

during the $1500 \mathrm{~km}$ journey

from Fowlers Bay to Albany.

Unveiled by

the HON. IAN TAYLOR M.L.A.

Deputy Premier of Western Australia

11 March 1991.

Presented by the Post Office Historical Society of WA

for the Sesquicentenary Celebration $1841-1991$.

Royal Western Australian Historical Society. ${ }^{76}$

The Shire of Esperance also erected a monument in 1991 to Eyre and Wylie, who 'passed this way' at Pink Lake. ${ }^{77}$ The Kimba District Council commissioned a giant sculpture of Eyre and an Aboriginal guide, unveiled in 2011 and partly funded by a Tourism Commission grant. Curiously, although the statues, both double life-sized, represent Eyre and an Aboriginal man and are closely allied to conventional popular images of Eyre and Wylie, the assemblage is known as 'The Edward John Eyre Statue' - Wylie had not joined the expedition at that point. The accompanying text describes it as 'an artistic tribute to Edward John Eyre and the indigenous men on whose bush skills he so often relied', and merely notes that Baxter perished, with no mention of how. ${ }^{78}$ The collective coyness about the murder contrasts with the efforts made by the Western Australian Historical Society in 1930 to erect a memorial to Baxter on the site of his remains. ${ }^{79}$

76 'Eyre, Baxter \& Wylie Expedition', Monument Australia, monumentaustralia.org.au/themes/landscape/ discovery/display/60462-eyre,-baxter-\&-wylie-expedition.

77 'Eyre \& Wylie Sesquicentenary', Monument Australia, monumentaustralia.org.au/themes/landscape/ discovery/display/60454-eyre-\&-wylie-sesequicentenary/photo/1.

78 'Edward John Eyre Sculptures', District Council of Kimba Attractions, www.kimba.sa.gov.au/page. aspx?u=297, accessed 3 July 2013. 


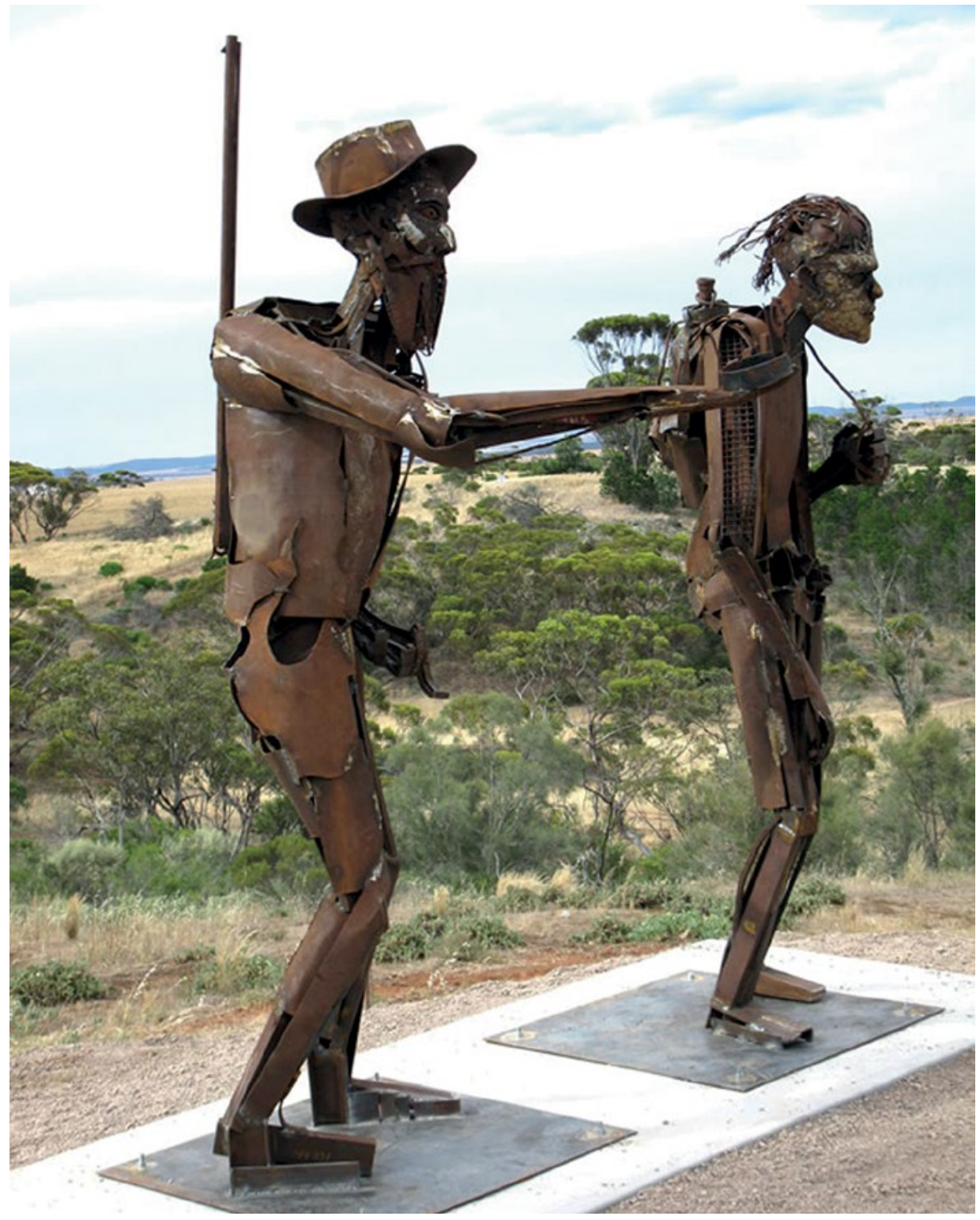

Figure 3.8 'The Edward John Eyre Statue', Kimba, South Australia (Marcus Possingham and Roland Weight, sculptors), unveiled 2011. Source: Courtesy Roland Weight.

Other guides were being recalled at the same time. Perhaps one of the more bizarre commemorations was the naming of a variety of barley after Tommy Windich in $1988 .{ }^{80} \mathrm{~A}$ Windich Street materialised in Esperance Bay and

80 Countryman (Perth), 6 October 1988: 14. 
a statue of Windich in a Coolgardie park. Tommy Windich's gravesite has been problematic. Tourists are encouraged to visit 'the final resting place' of Tommy Windich in the Port Authority Park, Esperance. ${ }^{81}$ Oddly, this is not Windich's final resting place but is called a 'memorial grave' and was constructed in $1988 .{ }^{82}$ The original grave, complete with white picket fence and granite headstone, overlooked the ocean in the sandhills on what became Port Authority property. The original gravesite, now without its original headstone or fence, sits between the Port's entry and exit roads. Recently a 'Historical Site' sign has been added. ${ }^{83}$ The siting of the 'memorial grave' in a public park suggests both that Windich was considered important but also that, as with other public memorial sites, accessibility was sometimes more important than accuracy in determining a place of public memory. ${ }^{84}$

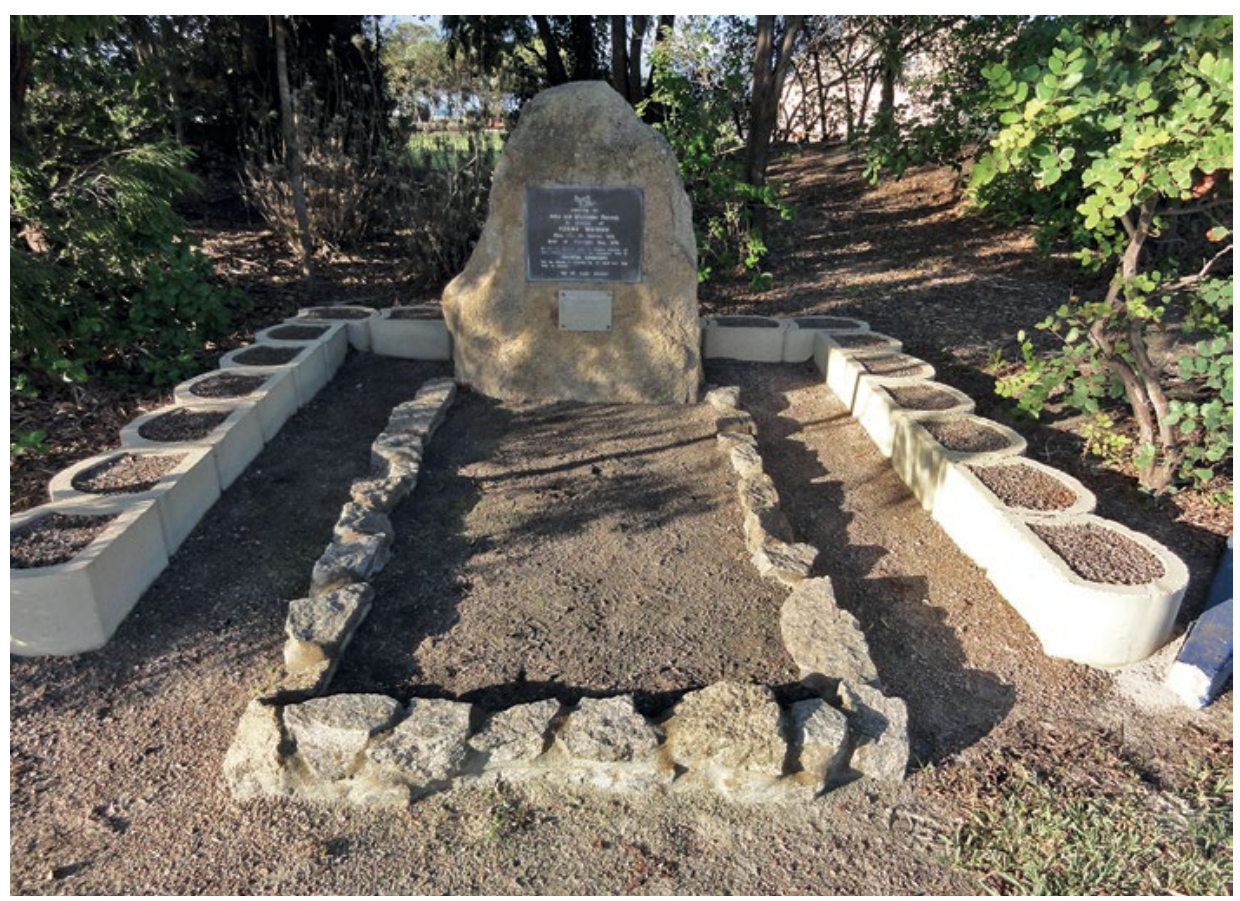

Figure 3.9 Windich 'memorial' grave, Esperance, Western Australia, erected in 1988.

Source: Courtesy Maryann Lankester, Esperance Museum.

81 'Australia's Golden Outback Holiday Planner 2014/2015': 58, www.wheatbelttourism.com/wp-content/ uploads/2012/04/ago-planner-2014_web.pdf, accessed 20 May 2014.

82 The original headstone was replaced in 1973 by a granite rock. See Esperance Advertiser, 5 January 1973. This rock was moved to the new site in the park in 1988 and a second plaque added. This plaque used the term 'memorial grave'.

83 The headstone was apparently damaged in the 1960s but was restored and is now in the Esperance Museum. 84 We are grateful to Maryann Lankester of the Esperance Museum for her research into the history of Tommy Windich's grave and memorial. 


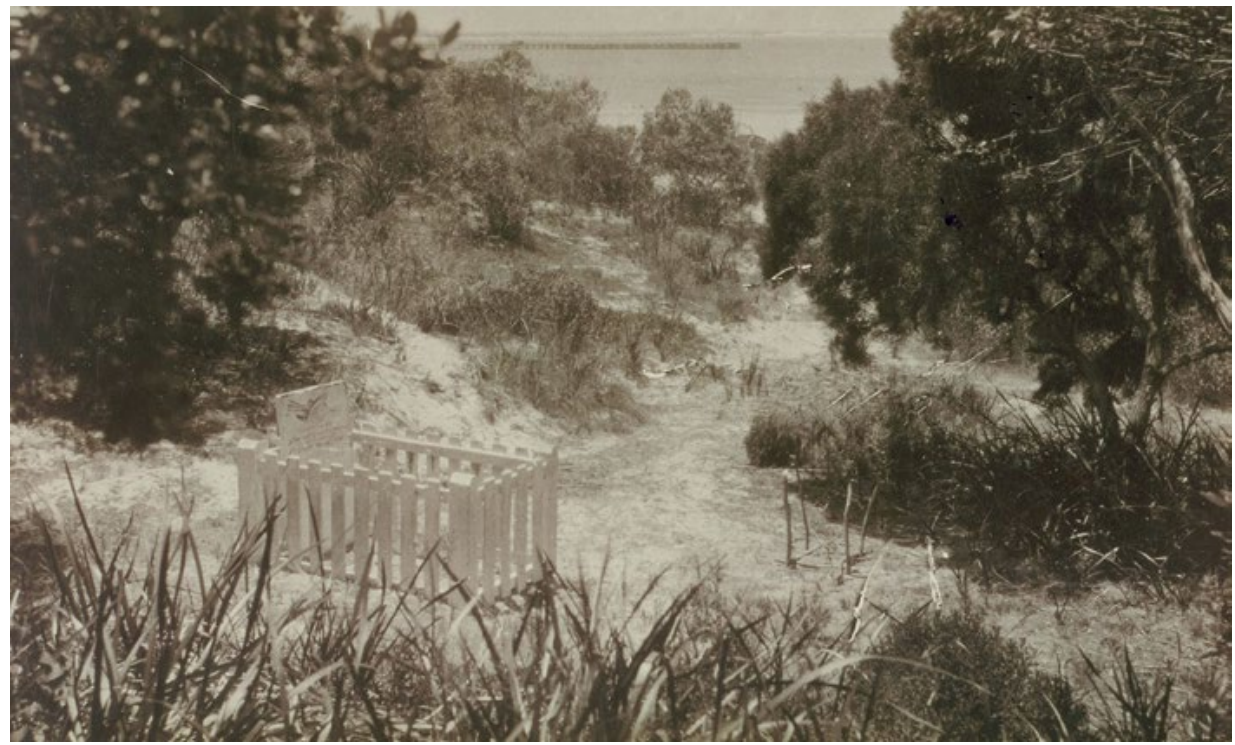

Figure 3.10 Original Windich grave with headstone, photographed 1938. Source: Courtesy Maryann Lankester, Esperance Museum.

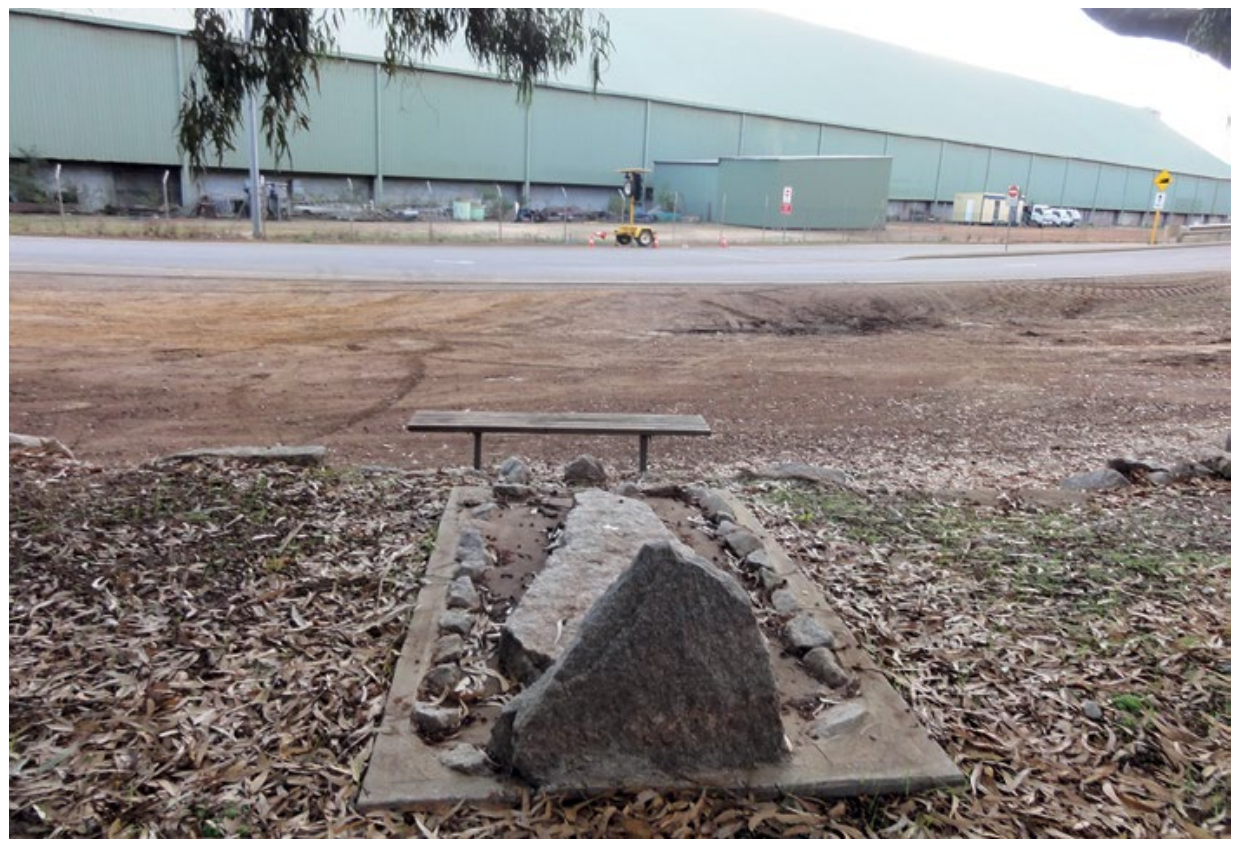

Figure 3.11 Original site of Windich's grave, as it is now, Esperance, Western Australia. The headstone is now in the Esperance Museum. Source: Courtesy Maryann Lankester, Esperance Museum. 
The new suburb of Ngunnawal in Canberra, created in 1995, focused on honouring a range of Aboriginal Australians, and included Bungaree Crescent, Mokare Street, Yuranigh Court and Windich Street. In north Queensland, a Jackey Jackey Coffee Shop appeared in Cooktown, and the very active Eacham Historical Society erected a statue commemorating Palmerston and Pompo in Millaa Millaa. In Western Australia, a 'Mokare heritage walk' was developed near Denmark, and local Albany residents commissioned a large statue of Mokare in 1997 as part of a Reconciliation project. This statue itself led to another type of recognition: it prompted historian Tiffany Shellam's exploration of contact history in the Albany district. Her research demonstrated the critical role of Mokare in establishing communication and mutual respect between the two cultures. ${ }^{85}$

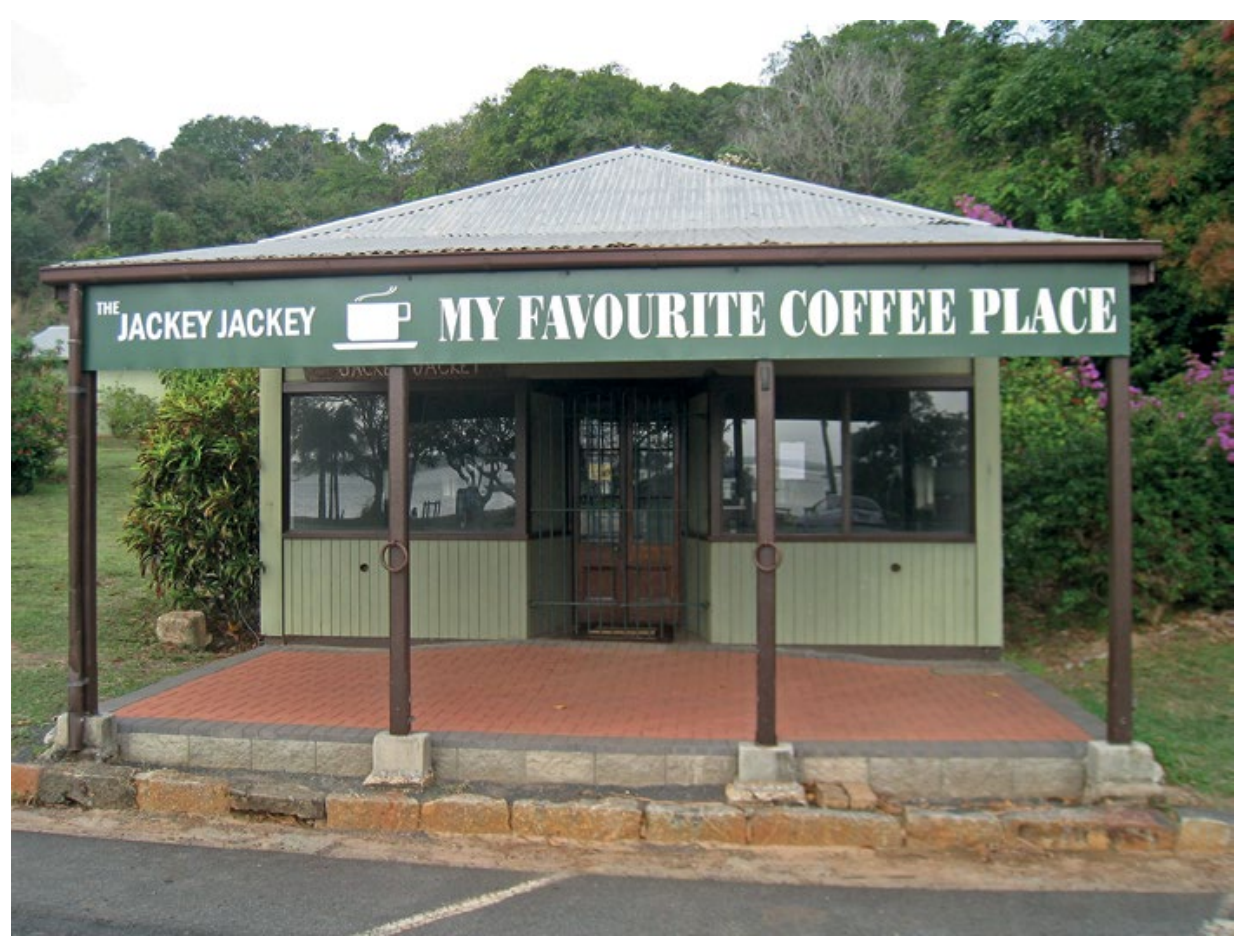

Figure 3.12: Jackey Jackey coffee shop, Cooktown, Queensland, 2010. Source: Courtesy Richard White. 


\section{Conclusion}

In the end we cannot say Indigenous participants in Australian exploration received no recognition. A number clearly were singled out for a particular kind of celebrity, and arguably they were - at the time, and now conclusively - given more recognition than other members of exploring parties apart from the leader. So the questions then become: what form did their recognition take, who promoted their celebrity and why did the popular recognition of their exploits ebb and flow over the years and in different contexts? We have argued that expedition leaders often genuinely acknowledged their debt to Aboriginal guides and recognised their particular skills, though they may have had self-interested motives in doing so. Many in the wider society accepted this acknowledgement. From the end of the nineteenth century, however, their celebrity waned, punctuated by the occasional local commemorations, until the breaking of the great Australian silence in the 1960s, after which commemoration and recognition became more apparent and tied into tourism and civic promotion.

A separate question is whether the recognition they received was sufficient or appropriate, given their contribution, and whether numbers of Indigenous participants who were not singled out should have been. That goes into larger and ultimately unanswerable questions of who gets recognised in history and who should be. Is history the story of 'Great Men' or of the collective souls of history - including Indigenous men and women - who never get a mention?

Finally, we know little of how these guides saw their own roles, but three interesting pieces of evidence suggest they saw themselves as in no way inferior to the designated leader of the expedition. From an Indigenous perspective, who was led and who was leader could be quite different. In the one extended account of an expedition given by an Aboriginal guide, Jackey Jackey talked consistently of what he 'told' Kennedy to do - 'to put the saddles on', 'to leave the horses', 'to look behind always', 'to sit down' - without any sense of this being unusual. ${ }^{86}$ On Leichhardt's second expedition, according to one member of the party, the explorer 'put himself under the guidance' of Harry Brown, who then successfully led the party home. When Leichhardt momentarily took over the lead and went the wrong way, 'Brown called out loudly - "He don't know the Road"' and returned to the lead. ${ }^{87}$ And finally there is Tommy Windich's

86 Carron 1849: 84-85.

87 Hely, Hovenden 1846-47, Journal of an Expedition Overland ..., Mitchell Library, C264: entries for 2 July 1847, 12 July 1847; Kennedy 2013: 162. 
much-publicised self-identification upon reaching the Overland Telegraph line during John Forrest's expedition in 1874, when he 'called out with enthusiasm, "Three cheers for Tommy Windich, the West Australian Explorer"". ${ }^{88}$

\section{Acknowledgements}

We would like to thank the editors for their suggestions and acknowledge the support of the Australian Research Council.

\section{References}

Anon 1968, 'Yuranigh (?-1850)', Australian Dictionary of Biography, National Centre of Biography, The Australian National University, adb.anu.edu.au/ biography/yuranigh-2829/text4059, accessed 12 January 2014.

Anon 2010, 'Jungun, white prince of the red desert', The Batavia Legacy: Shipwrecks, Castaways, Lost Explorers and White Tribes in Australia's History and Mythology, batavialegacy.wordpress.com, accessed 12 January 2014.

Baker, Don W.A. 1993, 'John Piper, "Conqueror of the interior"', Aboriginal History 17: 17-37.

-1998, 'Exploring with Aborigines: Thomas Mitchell and his Aboriginal guides', Aboriginal History 22: 36-50.

Beale, Edgar 1967, 'Jackey Jackey (?-1854)', Australian Dictionary of Biography, National Centre of Biography, The Australian National University, adb.anu. edu.au/biography/jackey-jackey-2264/text2897, accessed 12 January 2014.

Birman, Wendy 1967, 'Wylie (?-?)', Australian Dictionary of Biography, National Centre of Biography, The Australian National University, adb.anu.edu.au/ biography/wylie-2823/text4047, accessed online 18 July 2015.

Bladon, Paul, Ian Moffat, David Guilfoyle, Alice Bealand and Jennifer Milani 2011, 'Mapping anthropogenic fill with GPR for unmarked grave detection; a case study from an alleged location of Mokare's grave, Albany, Western Australia', Exploration Geophysics 42: 249-257.

Blyton, Greg 2012, 'Aboriginal guides of the Hunter region 1800-1850: a case study in Indigenous labour history', History Australia 9(3): 89-106.

88 South Australian Register, 7 November 1874: 2S; Inquirer, 15 March 1876: 3. 
Bolton, Geoffrey C. 1974, 'Palmerston, Christie (1850-1897)', Australian Dictionary of Biography, National Centre of Biography, The Australian National University, adb.anu.edu.au/biography/palmerston-christie-4361/ text7089, accessed 12 January 2014.

1988, 'Tommy Dower and the Perth newspapers', Aboriginal History 12: $79-84$.

Cadzow, Allison 2002, 'Waltzing Matildas: A Study of Select Australian Women Explorers', PhD thesis, University of Technology, Sydney.

Cahir, Fred 2010, "Are you off to The Diggings?": Aboriginal guiding to and on the goldfields', Latrobe Journal 85: 22-36.

Carron, William 1849, 'The Statement of the Aboriginal Native Jackey Jackey, who Accompanied Mr. Kennedy', in Narrative of an Expedition undertaken under the Direction of the Late Mr. Assistant Surveyor E. B. Kennedy, Kemp \& Fairfax, Sydney.

Carter, Paul 1987, The Road to Botany Bay: An Essay in Spatial History, Faber \& Faber, London.

Clarke, Ian D. and Fred Cahir (eds) 2013, The Aboriginal Story of Burke and Wills: Forgotten Narratives, CSIRO Publishing, Collingwood, Vic.

Clarke, Philip A. 2008, Aboriginal Plant Collectors: Botanists and Australian Aboriginal People, Rosenberg Publishing, Kenthurst, NSW.

Cohen, B.C. 1966, 'Collie, Alexander (1793-1835)', Australian Dictionary of Biography, National Centre of Biography, The Australian National University, adb.anu.edu.au/biography/collie-alexander-1911/text2267, accessed 14 January 2014.

Curthoys, Ann 2001, 'National narratives, war commemoration and racial exclusion in a settler society: the Australian case', in The Politics of War Memory and Commemoration, T.G. Ashplant, Graham Dawson and Michael Roper (eds), Routledge, London.

Driver, Felix 2013, 'Hidden histories made visible? Reflections on a geographical exhibition', Transactions of the Institute of British Geographers 38(3): 420-435.

Dutton, Geoffrey 1977, Edward John Eyre, the Hero as Murderer, Penguin, Ringwood, Victoria.

Eyre, Edward John 1845, Journals of Expeditions of Discovery Into Central Australia, T. \& W. Boone, London. 
INDIGENOUS INTERMEDIARIES

Favenc, Ernest 1888, The History of Australian Exploration from 1788 to 1888. Complied from State Documents, Private Papers and the most authentic sources of information, Turner \& Henderson, Sydney.

Findlay, Elisabeth 2013, 'Peddling prejudice: a series of twelve profile portraits of Aborigines of New South Wales', Postcolonial Studies 16(1): 2-27.

Forrest, John 1875, Explorations in Australia, London, gutenberg.net.au/ ebooks/e00051.html, accessed 12 February 2014.

Flinders, Matthew 1814, A Voyage to Terra Australis, G. and W. Nicol, London.

Foster, Elizabeth 1986, Explorers of Australia, Oxford University Press, Melbourne.

Green, Neville 2005, 'Mokare (1800-1831)', Australian Dictionary of Biography, National Centre of Biography, The Australian National University, adb.anu. edu.au/biography/mokare-13106/text23711, accessed 13 February 2014.

Griffin-Foley, Bridget 2011, 'Digging up the past: Frank Clune, Australian historian and multi-media personality', History Australia 8(1): 127-150.

Healy, Chris 1997, From the Ruins of Colonialism: History as Social Memory, Cambridge University Press, Melbourne.

Hely, Hovenden 1846-47, Journal of an Expedition Overland from Sydney to Darling Downs under Dr Leichhardt, 1 October 1846-July 28, 1847, Mitchell Library, State Library of New South Wales, ML C264.

Host, John and Jill Milroy 2001, 'Towards an Aboriginal labour history', in Wordal, Studies in Western Australian History no. 22, Jill Milroy, John Host and Tom Stannage (eds), University of Western Australia, Nedlands.

Jardine, Frank 1867, Narrative of the Overland Expedition of the Messrs. Jardine from Rockhampton to Cape York, Northern Queensland / compiled from the journals of the brothers, and edited by Frederick J. Byerley, J.W. Buxton, Brisbane.

Kennedy, Dane 2013, The Last Blank Spaces: Exploring Africa and Australia, Harvard University Press, Cambridge, MA.

Leichhardt, Ludwig 1847, Journal of an Overland Expedition in Australia from Moreton Bay to Port Essington ... during the Years 1844-1845, T. \& W. Boone, London.

McCarthy, Frederick 1952, 'Breast-plate: the Blackfellows' reward', The Australian Museum Magazine 10(10): 326-331. 
Mitchell, Thomas Livingstone 1839, Three Expeditions into the Interior of Eastern Australia: With Descriptions of the Recently Explored Region of Australia Felix, and of the Present Colony of New South Wales, T. \& W. Boone, London, gutenberg.net.au/ebooks/e00036.html\#mitchell2-07, accessed 14 February 2014.

-1848, Journal of an Expedition into the Interior of Tropical Australia: In Search of a Route from Sydney to the Gulf of Carpentaria, Longman, Brown, Green, and Longmans, London.

Nettlebeck, Amanda and Robert Foster 2010, 'Commemorating foundation: a study in regional historical memory', History Australia 7(3): 53.1-53.18.

Pannell, Sandra 2008, 'Aboriginal cultures in the Wet Tropics', in Living in a Dynamic Tropical Forest Landscape, Nigel E. Stork and Stephen M. Turton (eds), Blackwell, Oxford.

Parbury, Nigel 1986, Survival - A History of Aboriginal Life in New South Wales, Ministry of Aboriginal Affairs, Sydney.

Reynolds, Henry 1990, With the White People, Penguin, Ringwood, Victoria.

2000, Black Pioneers: How Aboriginal and Islander People Helped Build Australia, Penguin, Ringwood, Vic.

Sharp, Nonie 1992, Footprints along the Cape York Sandbeaches, Aboriginal Studies Press, Canberra.

Shellam, Tiffany 2009, Shaking Hands on the Fringe, University of Western Australia Press, Perth.

Smith, Keith Vincent 2005, 'Moowattin, Daniel (1791-1816)', Australian Dictionary of Biography, National Centre of Biography, The Australian National University, adb.anu.edu.au/biography/moowattin-daniel-13107/ text23713, accessed 12 February 2014.

Stanner, W.E.H. 1969, After the Dreaming: Black and White Australians an Anthropologist's View, ABC, Sydney.

Thomas, Martin 2015, 'The expedition as a cultural form: on the structure of exploratory journeys as revealed by the Australian explorations of Ludwig Leichhardt', in Expedition into Empire: Exploratory Journeys and the Making of the Modern World, Martin Thomas (ed.), Routledge, London.

Troy, Jakelin 1993, King Plates, A History of Aboriginal Gorgets, Aboriginal Studies Press, Canberra. 
INDIGENOUS INTERMEDIARIES

Yeats, Christine 2013, ‘1813 Blue Mountains crossing convict identified: Samuel Fairs - an extraordinary life', History: Royal Australian Historical Society Magazine, June, 10-11. 
This text is taken from Indigenous Intermediaries: New Perspectives on Exploration Archives, edited by Shino Konishi, Maria Nugent and Tiffany Shellam, published 2015 by ANU Press, The Australian National University, Canberra, Australia. 